
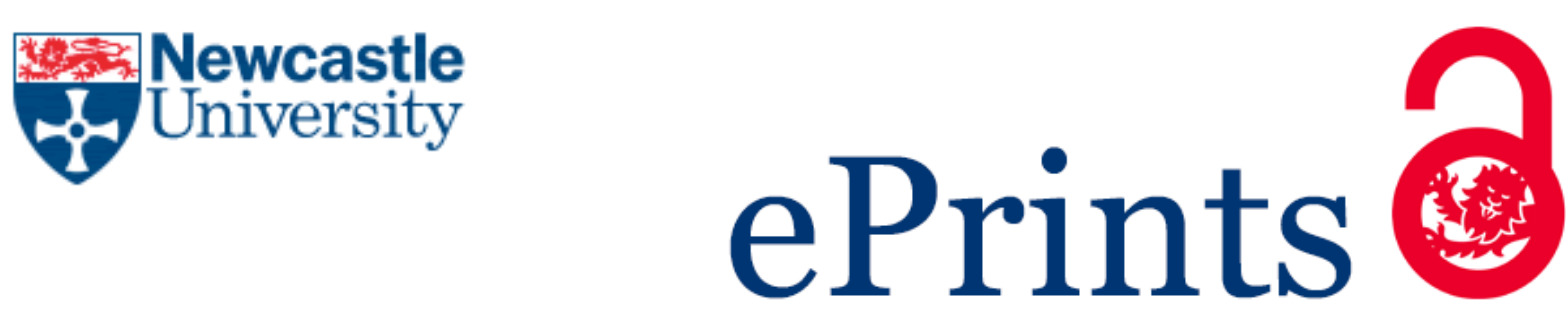

Mercier R, Kawai Y, Errington J.

Wall proficient $E$-coli capable of sustained growth in the absence of the Z-ring division machine.

Nature Microbiology 2016, 1(8), 16091.

\title{
Copyright:
}

This is the authors accepted manuscript of an article that has been published in its final form by Nature Publishing Group, 2016.

DOI link to article:

http://dx.doi.org/10.1038/nmicrobiol.2016.91

Date deposited:

$18 / 01 / 2017$

Embargo release date:

27 December 2016 


\section{Wall proficient E. coli capable of sustained growth in the}

2 absence of the Z-ring division machine

3

4 Romain Mercier ${ }^{1,2, *}$, Yoshikazu Kawai ${ }^{1}$ and Jeff Errington ${ }^{1, *}$

5

$6 \quad{ }^{1}$ Centre for Bacterial Cell Biology, Institute for Cell and Molecular Biosciences, Medical

7 School, Newcastle University, Richardson Road, Newcastle upon Tyne NE2 4AX, UK

8

9 '2Laboratoire de Chimie Bactérienne, Institut de Microbiologie de la Méditerranée, CNRS-Aix-

10 Marseille University, 31 Chemin Joseph Aiguier, 13009 Marseille, France

11

12

13

*Correspondence: rmercier@imm.cnrs.fr and jeff.errington@ncl.ac.uk

14

15

16 


\section{Summary}

The peptidoglycan (PG) cell wall is a major protective external sheath in bacteria and a key target for antibiotics ${ }^{1}$. PG is present in virtually all bacteria, suggesting that it has a very ancient origin, and was likely present in the last bacterial common ancestor ${ }^{2}$. Cell wall expansion is orchestrated by cytoskeletal proteins related to actin (MreB) and tubulin (FtsZ) ${ }^{3}$, which also emerged very early in evolution. FtsZ has been characterised in a wide range of organisms and is a key essential player in a highly organised division machine that directs an invaginating annulus of cell wall PG, together with the other various cell envelope layers. MreB plays an analogous role in directing growth of the lateral wall in cylindrical (rod shaped) organisms, which comprise the majority of extant bacterial forms. Recent work on cell wallless derived bacteria, called L-forms, has revealed that these cells require neither MreB nor FtsZ for growth and division ${ }^{4-6}$, consistent with the notion that these proteins are concerned exclusively with wall dynamics. Discovery that $f t s Z$ can be deleted in an L-form background recently provided, for the first time, a means of generating an ftsZ null mutant of $E$. coli. Remarkably, starting with this strain we have been able to isolate variants of $E$. coli that lack FtsZ but are capable of efficient growth in a walled state. Genetic analysis reveals that a combination of three mutations is needed for this phenotype. Importantly, the suppressive mutations lead to a major cell shape change, from the normal cylindrical shape to a branched and bulging, ramified shape, which we call "coli-flower". The results highlight the versatility and adaptability of bacterial cells and illustrate possible evolutionary routes leading to the emergence of specialised bacteria such as pathogenic Chlamydia or aquatic Planctomycetes, that lack FtsZ but retain the PG cell wall ${ }^{7-9}$. 


\section{Results and discussions}

Cell wall-free bacteria, also called L-forms, can regenerate their parental cell morphology in the absence of a pre-existing template ${ }^{6,10}$. In E. coli, the recovery of a walled rod-shaped morphology from a pleiomorphic L-form requires only a few cell division events $^{11,12}$. Here, we investigated the requirement of cell division events in the recovery process using an $E$. coli L-form strain lacking the essential cell division $f t s Z$ gene (Fig. 1a). As previously observed, when wild-type E. coli L-forms were cultured in the absence of a cell wall inhibitor, but presence of an osmotic stabiliser, the cells readily resumed growth and reverted to the rod-shaped walled state (Fig. 1b, top panels) $)^{6,11,12}$. In contrast, L-forms of the ftsZ deleted strain failed to grow under these conditions (Fig. 1b, bottom left panel). Microscopic observation revealed the presence of non-dividing filamentous cells in the ftsZdeleted strain (Fig. 1b, bottom right panel), showing that the cells are capable of resuming normal rod-shaped growth in the absence of a functional division apparatus, even though they cannot sustain long term proliferation.

Unexpectedly, after prolonged incubation of a plate bearing an ftsZ-deleted strain, several colonies appeared, presumably containing cell variants capable of growth (Supplementary Fig. 1a). After confirming that the colonies were variants of the original strain rather than contaminants, we tested their properties and found that they were of two general classes. One class had resumed growth as L-forms, presumably by acquiring mutations that block cell wall synthesis, and these were not studied further. The second class of mutants (CFL; coli-flower), however, appeared to comprise walled cells, and several lines of evidence suggested that these were mutants capable of walled growth in the absence of FtsZ. First, unlike L-forms, the CFL mutants were able to grow in either the absence or the presence of osmotic stabilisers (Supplementary Fig. 1b and 1c, right and left panels), although magnesium was needed to stabilise the CFL cells (Supplementary Fig. 1b-c, middle and right panels, and 1e-f, Supplementary video 1). Second, the CFL mutants grew in liquid media (Supplementary Fig. 1d), while E. coli L-forms are unable to proliferate under these 
conditions $^{6}$. Finally, in contrast to L-forms, the CFL mutant strains were highly sensitive to $\beta$ lactam antibiotics (Fig. 1c, Supplementary Fig. 1g).

In previous reports of experiments with FtsZ impaired strains, the cells were shown to continue to elongate normally for a few generation times, forming filamentous cells with approximately normal diameter (Fig. 1b, bottom right panel) but eventually all of the filaments lysed, with no long-term survivors (e.g. ${ }^{13}$ ). However, the CFL mutant cells turned out not to be filamentous but instead had a bulging, branching and highly pleiotropic morphology, which we call "coli-flower" (Fig. 1d). Typically, the cells tend to have several peripheral spherical areas, of differing size, connected to a central branched zone, which sometimes has a more or less cylindrical shape but with varying width. Interestingly, despite the pleiotropy of cell morphology, DNA staining revealed a relatively homogeneous distribution of chromosomal DNA in the cell, both in the branching and spherical areas (Supplementary Fig. 2).

Remarkably, when we reintroduced the ftsZ gene into a CFL mutant strain an almost normal rod shaped cell morphology was returned (Fig. 1e, Supplementary Fig. 3a-d), revealing that none of the putative ftsZ-suppressing mutations are required to maintain the wild type cell shape. Batch cultures of the CFL mutants showed a biphasic growth pattern, with a mass doubling time of about 60 min in exponential phase (Fig. 1f and Supplementary Fig. 4e), comparable to isogenic FtsZ ${ }^{+}$strains (58 min) (Fig. 1f and Supplementary Fig. 4d). Moreover, measurement of the viable cell count (colony forming units; CFU) revealed that the cells are capable of reasonably efficient proliferation (Fig. 1g).

Time-lapse imaging was used to elucidate the formation of "coli-flower" like cells and how they divide. In the examples shown (Fig. 2a-c and Supplementary Videos 2-5) a more or less round cell expanded in two main directions to generate two new spherical areas connected by a newly formed branch (Fig. 2a, 17 to 85 min and Supplementary Video 1). Further blebs emerged from the original branch zone, leading in turn to the formation of additional new-branched spherical areas (Fig. 2a, stars and Supplementary Videos 2-3). Expansion of the spherical areas seemed to coincide with a reduction of material in the central zone, leading to an area with extensive narrow ramifications (Fig. 2a and 
Supplementary Videos 2-3). Remarkably, despite the absence of an ftsZ-based division machine, separation-like events frequently occurred (Fig. 2 Arrows and Supplementary Videos 2-4-5). These events were observed both in branching areas (Fig. 2a, $279 \mathrm{~min}, 2 \mathrm{~b}$, 28-35 min and $2 \mathrm{c}, 35-45 \mathrm{~min}$ and $70-85 \mathrm{~min}$ ) and at the neck of globular areas, generating more or less spherical progeny cells (Fig. 2b, 20-25 min and 2c, 55-70 min).

Whole genome sequencing of three independent ftsZ-less mutant strains revealed the presence of multiple differences to the parental strain (Supplementary Table 1). These mutations seemed to be of three main classes. First, all of the mutants had an inactivating mutation in either the gene $(m r c B)$, for the bi-functional Penicillin Binding Protein 1B (PBP1B) or for its essential extracellular regulator $\mathrm{LpoB}^{14,15}$. PBP1B is partially redundant to PBP1A and is thought mainly to be concerned with wall synthesis during cell division ${ }^{15,16}$. Secondly, two of the mutants had (different) mutations in the gene Ipp, which encodes the major lipoprotein Lpp (Braun's lipoprotein), which physically connects the outer-membrane to the peptidoglycan ${ }^{17}$. One of these mutations would delete the last four amino acids of the Lpp protein, including the Lysine that is essential for attachment to the peptidoglycan (Supplementary Table 1). Finally, all three of the mutants had diverse mutations affecting the synthesis of various extracellular polysaccharides: lipopolysaccharide, the Enterobacterial Common Antigen (ECA) or colanic acid (Supplementary Table 1).

To test which of these mutations were needed for the switch to the CFL mode of growth, we carried out genetic reconstruction experiments in which null mutations in the various genes were introduced into a $\Delta f t s Z$ strain carrying a plasmid pOU82-fts $Z^{+}$that enables normal growth and division in the walled state. The cells were further engineered so that this plasmid could be eliminated by addition of IPTG (see Methods). As a control, IPTG was added to one of the original ftsZ-less walled mutant strains ( $\Delta$ ftsZsup5, bearing $m r c B$ and Ipp mutations) carrying the plasmid pOU82-ftsZ. The strain readily lost the plasmid (which carries a lacZ gene), as shown by the emergence of white colonies on X-gal plates (Lac; Fig. 3a) and loss of the ftsZ gene was confirmed by multiplex PCR (Supplementary Fig. $4 a$, line 1). In contrast, reconstructed strains bearing $\Delta f t s Z$ and either $\Delta / p o B$ or $\Delta l p p$, showed 
prolonged retention of the ftsZ plasmid (Fig. 3a, $\Delta f t s Z / \Delta / p p$ and $\Delta f t s Z / \Delta / p o B$; Supplementary

124 Fig. 4a, lanes 2 and 3). Phase contrast microscopy revealed that depletion of ftsZ in either $\Delta / p o B$ or $\Delta l p p$ mutants led to the formation of filamentous cells but not CFL-like cells (Fig. 3a). In contrast, a strain bearing both $\Delta l p p$ and $\Delta l p o B$ deletions readily lost the plasmid (Fig. 3a, $\Delta f t s Z / \Delta / p p / \Delta / p o B$; Supplementary Fig. 4a lane 4). Examination of its morphology revealed a CFL phenotype similar to that of the original suppressed ftsZ strains (Fig. 3a, lower left and right panels), thus revealing that combined disruption of the $I p \circ B$ and $I p p$ genes is sufficient to enable walled cells to tolerate loss of ftsZ by switching into the CFL mode of proliferation, although secondary mutations frequently arise that then enable more robust growth (Supplementary Data 1 and Fig. 4c-d). This effect was specific for the IpoB/PBP1B pathway because in reconstructed strains containing $\Delta f t s Z \Delta l p p$ and deletions in the related IpoA/PBP1A pathway ${ }^{15}$ loss of the ftsZ plasmid was not permitted (Supplementary Fig. 4b), In the above reconstruction experiments it is important to note that the switch to the CFL state occurred in walled cells without going through an L-form intermediate. We also tested the genetic requirements for CFL growth starting from the L-form $\Delta f t s Z$ state. In accordance with the above results, when L-forms bearing $\triangle f t s Z$ and either $\Delta / p o B$ or $\Delta m r c B$ (PBP1B) were streaked in the absence of a cell wall inhibitor (no phosphomycin), but presence of an osmotic stabiliser, colonies appeared with high efficiency (Fig. 3b), suggesting an efficient conversion to the CFL state. In contrast, virtually no colonies appeared from L-forms bearing $\Delta f t s Z$ only or $\Delta f t s Z$ and either $\Delta l p o A$ or $\Delta m r c A$. The strain bearing $\Delta f t s Z$ and $\Delta l p p$, gave an intermediate result, suggesting that, unlike $I p o B / m r c B$,

144 mutation of Ipp is not sufficient to enable an efficient L-form to CFL transition and perhaps the acquisition of a secondary mutation is required (Fig. 3b).

To further investigate the role of these mutations (i.e. IpoB, Ipp and colanic acid) in CFL growth, we introduced plasmids bearing arabinose-inducible $I p o B, \operatorname{mrcB}$, Ipp or wcaJ

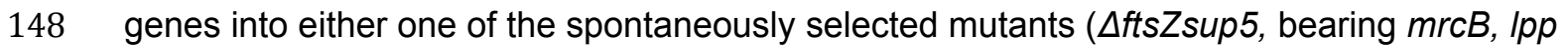
149 and wcaJ mutations) or the reconstructed strain containing deletions in ftsZ, Ipp and IpoB $150\left(\Delta f t s Z / \Delta / p p / \Delta / p o B_{\text {sup }}\right)$. Addition of the inducer, arabinose, had no major effect on growth or 
151 morphology for strains carrying inducible wcaJ or Ipp genes (Supplementary Data 2 and Fig.

152 5). However, induction of $I p o B$, in the strain $\Delta f t s Z / \Delta / p p / \Delta / p o B_{\text {sup }}$, and $m r c B$, in the strain $153 \Delta$ ftsZsup5, abolished growth (Fig. $4 a,+l p o B$ and $4 c,+m r c B$ ). (Expression of $I p o B$ in an 154 isogenic fts $Z^{+}$strain had no effect; Supplementary Fig. 6a). Phase contrast and time-lapse

155 imaging of cells in the absence of inducer revealed the expected branching and bulging 156 pattern of growth (Supplementary Fig. $6 \mathrm{~b}$ and Video 6). However, the IpoB or mrcB induced 157 cells behaved in a strikingly different manner, reverting slowly to a rod-shaped morphology, 158 and then forming elongated filamentous cells that did not divide (Fig. 4b, $d$ and e, 159 Supplementary Video 7), similar to an ftsZ depleted, otherwise wild type strain. Thus, our 160 results show that loss of PBP1B synthesis or activity is required for the CFL mode of cell 161 growth but that Ipp or wcaJ lesions are less or not important. Additionally, we also showed 162 that the cell wall elongation system is required for CFL growth (Supplementary Data 3 and 163 Fig. 7).

164 To our knowledge, this is the first report of growth and viability of a walled $E$. coli ftsZ null mutant, after 35 or so years of study. It seems likely that several labs will have had the need or opportunity to attempt to generate such mutants but because effective suppression in the walled state requires two or more independent mutations, the frequency at which viable mutants would occur would normally be extremely low. Our ability to isolate such a mutant emerged by studying L-form (wall-free) bacteria, which use a Z-ring-independent means of proliferation ${ }^{4,6}$. This illustrates the power of the L-form system for studying the

171 fundamental processes of cell wall synthesis and cell division.

172 We have also not been able to find previous reports of the strange CFL cell 173 morphology. The dramatic morphological transition requires inactivation of both FtsZ and 174 PBP1B. The lethality that occurs when $I p o B$ or $m r c B$ are reactivated in CFL strains (Fig. 4) appears to be associated with reversion to a more regular rod-shaped morphology. We

176 suppose that the relatively constant cell diameter associated with rod-shaped growth is 177 incompatible with the ability of ftsZ deficient cells to divide. Indeed, CFL cells seem to 178 undergo division at deeply pinched sites either in narrow tubes or at the junctions between 
bulbous cell structures. If so, the role of the PBP1B lesion would be to block the cylindrical

180

181

182

183

184

185

186

187

188

189

190

191

192

193

194

195

196

197

198

199

200

201

202

203

204

205

206 extending mode of cell growth, and or enable the bulging, branching mode of growth. The efficiency of CFL growth and transition into this state seems to be sensitive to the presence of a range of additional mutations, including $I p p$ and various extracellular polymers. Further work will be needed to dissect the roles of these factors.

Although lacking the normal cell division machinery, these $E$. coli ftsZ-less mutants divide efficiently (Fig. 1f-g), suggesting the existence of an effective mode of cell-cell separation in absence of ftsZ. The vast majority of known bacteria seem to rely on the FtsZbased division machinery for proliferation and, usually, for viability. However, there are striking examples among both pathogens (e.g. chlamydia) and free-living bacteria (e.g. Planctomyces), that have dispensed with FtsZ. Phylogenetic trees suggest strongly that these organism are descended from bacteria that once possessed FtsZ. Our results demonstrate that only one or two mutations are needed to enable a dramatic evolutionary switch from dependence to independence of the $Z$ ring machine and highlight the extraordinary evolutionary adaptability of the bacteria.

\section{References}

1 Schneider, T. \& Sahl, H. G. Lipid II and other bactoprenol-bound cell wall precursors as drug targets. Curr Opin Investig Drugs 11, 157-164, (2010).

2 Errington, J. L-form bacteria, cell walls and the origins of life. Open Biol 3, 120143, (2013).

3 Typas, A., Banzhaf, M., Gross, C. A. \& Vollmer, W. From the regulation of peptidoglycan synthesis to bacterial growth and morphology. Nat Rev Microbiol 10, 123-136, (2012).

4 Leaver, M., Domínguez-Cuevas, P., Coxhead, J. M., Daniel, R. A. \& Errington, J. Life without a wall or division machine in Bacillus subtilis. Nature 457, 849-853, (2009).

5 Mercier, R., Domínguez-Cuevas, P. \& Errington, J. Crucial role for membrane fluidity in proliferation of primitive cells. Cell Rep 1, 417-423, (2012). 
2076 Mercier, R., Kawai, Y. \& Errington, J. General principles for the formation and

208 proliferation of a wall-free (L-form) state in bacteria. Elife 3, (2014).

2097 Pilhofer, M. et al. Discovery of chlamydial peptidoglycan reveals bacteria with murein

210 sacculi but without FtsZ. Nat Commun 4, 2856, (2013).

2118 Liechti, G. W. et al. A new metabolic cell-wall labelling method reveals peptidoglycan

212 in Chlamydia trachomatis. Nature 506, 507-510, (2014).

2139 Jeske, O. et al. Planctomycetes do possess a peptidoglycan cell wall. Nat Commun 6,

$2147116,(2015)$.

21510 Kawai, Y., Mercier, R. \& Errington, J. Bacterial cell morphogenesis does not require a

216 preexisting template structure. Curr Biol 24, 863-867, (2014).

21711 Ranjit, D. K. \& Young, K. D. The Rcs stress response and accessory envelope

218 proteins are required for de novo generation of cell shape in Escherichia coli. $J$

219 Bacteriol 195, 2452-2462, (2013).

22012 Billings, G. et al. De novo morphogenesis in L-forms via geometric control of cell

221 growth. Molecular Microbiology 93, 883-896, (2014).

22213 Dai, K. \& Lutkenhaus, J. ftsZ is an essential cell division gene in Escherichia coli. J

223 Bacteriol 173, 3500-3506, (1991).

224 Paradis-Bleau, C. et al. Lipoprotein cofactors located in the outer membrane activate

225 bacterial cell wall polymerases. Cell 143, 1110-1120, (2010).

22615 Typas, A. et al. Regulation of peptidoglycan synthesis by outer-membrane proteins.

$227 \quad$ Cell 143, 1097-1109, (2010).

22816 Gray, A. N. et al. Coordination of peptidoglycan synthesis and outer membrane

229 constriction during Escherichia coli cell division. Elife 4, (2015).

23017 Braun, V. \& Bosch, V. Repetitive sequences in the murein-lipoprotein of the cell wall

231 of Escherichia coli. Proc Natl Acad Sci U S A 69, 970-974, (1972).

232

233

234 
236 We thank Tâm Mignot for hosting parts of the work in his laboratory, Waldemar Vollmer for

237 the gift of the plasmid pBAD33-IpoB and comments on the manuscript, Henrik Strahl and

238 Leon Espinosa for helpful discussion. This work was funded by European Research Council

239 Advanced Investigator Grants (\# 250363 and \# BH141574) to JE.

\section{Author contributions}

241 R.M. designed the experiments. R.M. performed the experiments. R.M. and Y.K. analysed

242 the data. R.M. and J.E. wrote the manuscript.

243

244 Competing Financial interests

245 The authors declare no competing financial interests

247 Figure Legends

248 Figure 1: Isolation and characterisation of walled Escherichia coli ftsZ-less strains

249 a, Summary of the morphological transitions described in the paper.

250 b, Cell wall reversion of $E$. coli L-form strains wild type (TB28, top left) and RM349 ( $\Delta$ ftsZ,

251 bottom left), following removal of the PG precursor synthesis inhibitor fosfomycin. Cells were

252 cultured on L-form-supporting medium (NA + MSM) plates (left). Representative phase

253 contrast images (right) show cell wall reverted E. coli wild type (top) and RM349 (bottom)

254 cells after $12 \mathrm{~h}$ incubation.

255 c, Growth of the strain $\Delta$ ftsZsup5 on NA+20 mM Mg${ }^{2+}$ plates with or without $10 \mu \mathrm{g} / \mathrm{ml}$ of 256 Ampicillin, as indicated.

257 d, Phase contrast microscopy of cells of three independent $\Delta$ ftsZsup strains grown in NB 258 with $20 \mathrm{mM} \mathrm{Mg}^{2+}$.

259 e, Phase contrast microscopy of the $\Delta f t s Z s u p 5$ cells grown in NB with $20 \mathrm{mM} \mathrm{Mg}^{2+}$, after 260 reintroduction of the plasmid pOU82-ftsZ. 
f, Growth profile of the strain $\triangle$ ftsZsup5, in presence (blue) or absence (red) of the plasmid

262

263

264

265

266

267

268

269

270

271

272

273

274

275

276

277

278

279

280

281

282

283

284

285

286

287

288 pOU82-ftsZ, in NB with $\mathrm{Mg}^{2+}$. The mass doubling time calculated for the strain $\triangle$ ftsZsup5 is about $58 \mathrm{~min}$ in presence and $60 \mathrm{~min}$ in the absence of FtsZ.

g, Colony-forming units of the strain $\Delta$ ftsZsup5, grown in the presence (blue) or absence (red) of the plasmid pOU82-ftsZ, corresponding to the growth profile from $\mathbf{f}$.

Scale bars, $3 \mu \mathrm{m}$.

Figure 2: Time lapse imaging of a CFL strain grown in the complete absence of FtsZ a-c, E. coli $\Delta$ ftsZsup strains grown in NB with $20 \mathrm{mM} \mathrm{Mg}^{2+}$ were observed by time-lapse phase contrast microscopy. Elapsed time (min) is shown in each panel. Scale bars, $3 \mu \mathrm{m}$. Stars identify blebs emerging from the original branch zone and arrows point to division events.

Figure 3: PBP1B activity inactivation is required for the transition to a CFL mode of proliferation in the absence of FtsZ

a, ftsZ loss assays (top) of RM446 ( $\Delta f t s Z s u p 5), \mathrm{RM} 411$ ( $\Delta f t s Z / \Delta / p o B), \mathrm{RM} 413$ ( $\Delta f t s Z / \Delta / p p)$ and RM419 ( $\triangle \mathrm{ftsZ} / \Delta / \mathrm{pp} / \Delta / \mathrm{poB})$ strains, containing the plasmids pOU82-ftsZ and pKG339. Walled cells were streaked on NA plates with $20 \mathrm{mM} \mathrm{Mg}^{2+}$, Tetracycline, IPTG and Xgal. The loss of ftsZ results in the formation of white colonies, which was verified by multiplex PCR (Supplementary Fig 4a). Corresponding cell morphologies (bottom) of the different streaked strains were imaged by phase contrast microscopy.

b, Cell wall reversion of E. coli L-form strains RM349 ( $\Delta$ ftsZ), RM411 ( $\Delta$ ftsZ/AlpoB), RM451 ( $\Delta f t s Z / \Delta m r c B), \operatorname{RM} 413(\Delta f t s Z / \Delta / p p), \operatorname{RM} 453(\Delta f t s Z / \Delta / p o A)$ and RM452 ( $\Delta f t s Z / \Delta m r c A)$ lacking pOU82-ftsZ, following removal of the PG precursor synthesis inhibitor fosfomycin. Cells were cultured on L-form-supporting medium (NA + MSM) plates.

Figure 4: PBP1B activity inhibits CFL proliferation by restoration of cylindrical cell shape morphology in the absence of FtsZ 
a, Growth of the strain RM445 ( $\left.\Delta f t s Z / \Delta / p p / \Delta / p o B_{\text {sup }}\right)$, carrying the plasmid pBAD33-IpoB, streaked on $\mathrm{NA}+20 \mathrm{mM} \mathrm{Mg}^{2+}$ plates in absence (left) or presence (right) of the inducer for IpoB expression (Arabinose).

b, Phase contrast microscopy of RM445 ( $\left.\Delta \mathrm{ftsZ} / \Delta / \mathrm{pp} / \Delta / \mathrm{po} B_{\text {sup }}\right) \mathrm{pBAD33-IpoB}$ cells from $\mathbf{b}$ in

293 the presence of arabinose.

294 c, Growth of the strain RM362 (AftsZsup5), carrying the plasmid pBAD33-mrcB, streaked on

$295 \mathrm{NA}+20 \mathrm{mM} \mathrm{Mg}^{2+}$ plates in absence (left) or presence (right) of the inducer for $m r c B$ 296 expression inducer (Arabinose).

297 d, Phase contrast microscopy of RM362 cells ( $\Delta$ ftsZsup5), carrying pBAD33-mrcB from $\mathbf{c}$ in 298 the presence of arabinose.

299 e, Strain RM445 ( $\left.\Delta f t s Z / \Delta / p p / \Delta / p o B_{\text {sup }}\right)$, carrying the plasmid pBAD33-IpoB, grown on

$300 \mathrm{NA} / \mathrm{Mg}^{2+}$ with arabinose, was observed by time-lapse phase contrast microscopy. Elapsed 301 time (min) is shown in each panel.

302 Scale bars, $3 \mu \mathrm{m}$.

\section{Methods}

Bacterial strains, plasmids and growth conditions

306 The bacterial strains and plasmids constructs used in this study are shown in Supplementary

307 Table 3. DNA manipulations, E. coli $\mathrm{DH} 5 \alpha$ transformation and $\mathrm{P} 1$ phage transduction were

308 carried out using standard methods ${ }^{18}$. Briefly, the plasmid pOU82-Cm-ftsZ was constructed

309 by insertion, by the Lambda Red recombinase system ${ }^{19}$, of the chloramphenicol cassette

310 from pKD3 into pOU82-Amp-ftsZ. The plasmids pBAD33-Ipp, pBAD33-wcaJ and pBAD33-

$311 m r c B$ were constructed by insertion of the coding sequences of the Ipp, wcaJ and $m r c B$

312 genes into pBAD33 digested by the restriction enzymes Kpnl and HindllI or Xbal. The

313 plasmid pBAD24-Ipp was constructed by insertion of the coding sequence of the Ipp into

314 pBAD24 digested by the restriction enzymes EcoRI and HindIII. E. coli L-forms were

315 prepared and grown, as previously described ${ }^{6}$, in osmoprotective medium composed of $2 \mathrm{x}$ 
MSM media pH 7 (40 mM MgCl $2,1 \mathrm{M}$ sucrose and $40 \mathrm{mM}$ maleic acid) mixed 1:1 with $2 \mathrm{x}$ NBA (Nutrient Broth with 2\% Agar (Oxoid)) in presence of fosfomycin (FOS) at $0.4 \mathrm{mg} / \mathrm{ml}$. E. coli CFL mutant strains were firstly selected on MSM/NBA and then further cultured on Nutrient Broth (NB, Oxoid) or Nutrient Broth 1\% Agar in the presence of $20 \mathrm{mM} \mathrm{MgCl}_{2}$. Unless specified, the various $E$. coli strains are incubated at $30^{\circ} \mathrm{C}$. When necessary, antibiotics and supplements were added to media at the following concentrations: ampicillin, 10 or $100 \mu \mathrm{g} / \mathrm{ml}$; mecillinam, $5 \mu \mathrm{g} / \mathrm{ml}$; aztreonam, $0.05 \mu \mathrm{g} / \mathrm{ml}$; A22 (sigma), $10 \mu \mathrm{g} / \mathrm{ml}$ chloramphenicol, $25 \mu \mathrm{g} / \mathrm{ml}$; kanamycin, $25 \mu \mathrm{g} / \mathrm{ml}$; tetracycline, $10 \mu \mathrm{g} / \mathrm{ml}$; spectinomycin, 50 $\mu \mathrm{g} / \mathrm{ml} ; \mathrm{MgCl}_{2}$, various concentrations; arabinose, $0.2 \%$; glucose, $0,5 \%$; Sodium Dodecyl

325 Sulfate (SDS), 0,5\%; IPTG, $1 \mathrm{mg} / \mathrm{ml}$ and X-gal, $4 \%$.

Plasmid pOU82-ftsZ loss assay

328 Various $E$. coli strains bearing the plasmid pOU82-ftsZ were transformed with the plasmid 329 pKG339 20 and plated on NA with tetracycline at $30^{\circ} \mathrm{C}$ for 3 days. Strains carrying both 330 plasmids were streaked on NA plates with $20 \mathrm{mM} \mathrm{Mg}^{2+}$, Tetracycline, IPTG and X-gal and 331 incubated at $30^{\circ} \mathrm{C}$ for 3-4 days. White colonies were streaked on NA plates with $20 \mathrm{mM} \mathrm{Mg}^{2+}$ 332 and X-gal.

\section{Transformation of $E$. coli ftsZ-less strains}

334 A $1 \mathrm{ml}$ sample of an overnight culture of an E. coli CFL strain was suspended in $200 \mu \mathrm{l}$ of 335 TSB, containing $20 \%$ glycerol, 10 \% PEG (MW 3350), 5 \% DMSO, $10 \mathrm{mM} \mathrm{Mgcl}$, $10 \mathrm{mM}$ $336 \mathrm{MgSO}_{4}$ in NB. A plasmid of interest was added and incubated on ice for $30 \mathrm{~min}$. After heat 337 shock at $37^{\circ} \mathrm{C}$ for $5 \mathrm{~min}, 1 \mathrm{ml}$ of NB with $20 \mathrm{mM} \mathrm{Mgcl}_{2}$ was added and the sample was 338 incubated for $30 \mathrm{~min}$ at $30^{\circ} \mathrm{C}$. The sample was plated on NB $1 \%$ Agar with $20 \mathrm{mM} \mathrm{Mgcl}_{2}$ and 339 the appropriate antibiotic and incubated at $30^{\circ} \mathrm{C}$. 
341 Mutiplex PCR was performed as described by ${ }^{6}$. Briefly, E. coli genomic DNA was purified

342 using a standard phenol-chloroform extraction protocol. The primers were designed using

343 MPprimer software ${ }^{21}$ and the recommended procedure was used for the PCR reaction.

\section{Genome sequencing and SNPs identification}

345 Whole genome sequencing was performed with the Illumina HiSeq 2000 System (GATC-

346 Biotech, Germany). Sequencing samples were prepared using a standard chloroform/phenol

347 extraction procedure. Sequence reads were aligned with CLC Workbench (CLC Bio-Qiagen,

348 Aarhus, Denmark) software using the NCBI E. coli MG1655 genome (GenBank: U00096.3)

349 as reference. SNPs and deletion/insertion were also analysed with the CLC Workbench

350 software.

\section{Microscopy and image analysis}

352 For snap-shot and time-lapse microscopy, exponentially growing cultures of the different CFL 353 walled strains were mounted and sealed on microscope slides covered with a thin film of $1 \%$ 354 agarose, in NB containing 20mM magnesium. Antibiotics, DAPI and arabinose were added in 355 the agar pad, as necessary. The cells were imaged for snap-shot microscopy on a Zeiss

356 Axiovert 200M (Zeiss $\times 100$ Plan-Neofluar oil immersion objective) microscope, and for time-

357 lapse microscopy, on a Nikon Eclipse Ti (Nikon × 100 Plan Fluor oil immersion objective)

358 contained in a temperature control chamber at $30^{\circ} \mathrm{C}$. Images were acquired with Metamorph

3596 (Molecular Devices). Pictures and movies were prepared for publication using ImageJ

360 (http://rsb.info.nih.gov/ij) and Adobe Photoshop.

361

\section{Method references}

36318 Sambrook, J., Fritsch, E.F., and Maniatis, T. Molecular Cloning: A Laboratory Manual. 364 Cold Spring Harbor: Cold Spring Harbor Laboratory Press, (1989). 
36519 Datsenko, K. A. \& Wanner, B. L. One-step inactivation of chromosomal genes in 366 Escherichia coli K-12 using PCR products. Proc Natl Acad Sci U S A 97, 6640-6645, 367 (2000).

36820 Jensen, R. B., Grohmann, E., Schwab, H., Diaz-Orejas, R. \& Gerdes, K. Comparison 369 of $c c d$ of $\mathrm{F}$, parDE of RP4, and parD of R1 using a novel conditional replication 370 control system of plasmid R1. Mol Microbiol 17, 211-220, (1995).

37121 Shen, Z. et al. MPprimer: a program for reliable multiplex PCR primer design. BMC 372 Bioinformatics 11, 143, (2010).

373

374 
a

E. coli walled E. coli L-forms $\Delta f t s Z$ $\Delta$ ftsZ/pftsZ
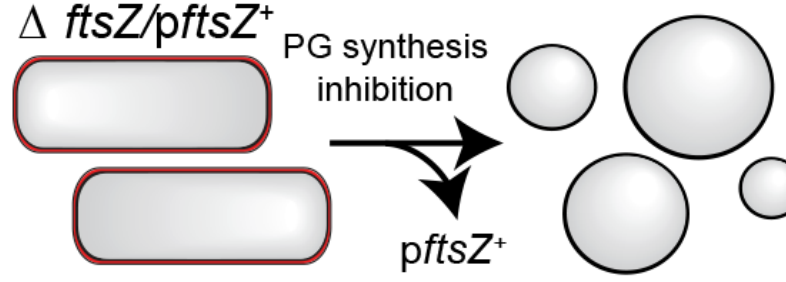

De novo PG

E. coli walled $\Delta$ ftsZ filaments?

— Peptidoglycan (PG) — cell membrane

b
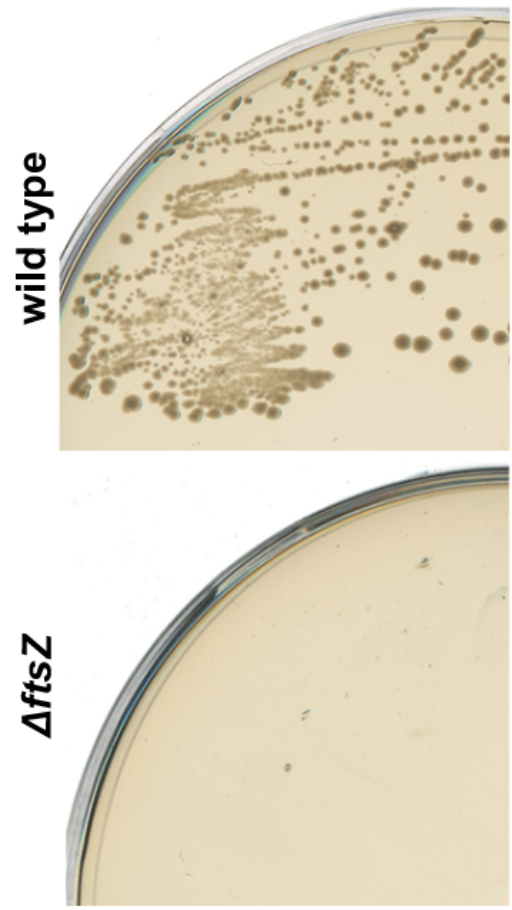

d
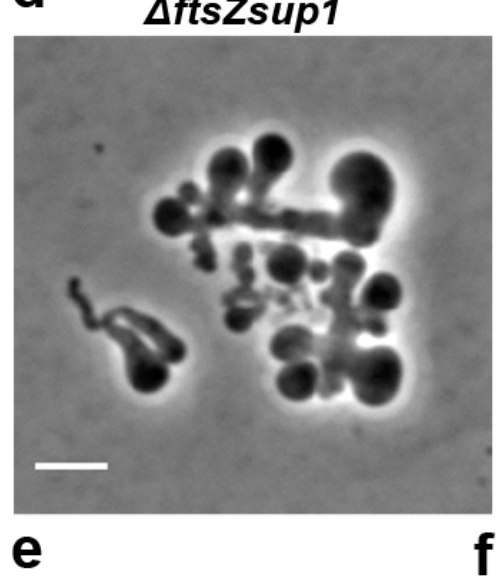

$\Delta f t s Z s u p 5 / p 0 u 82$-ftsZ
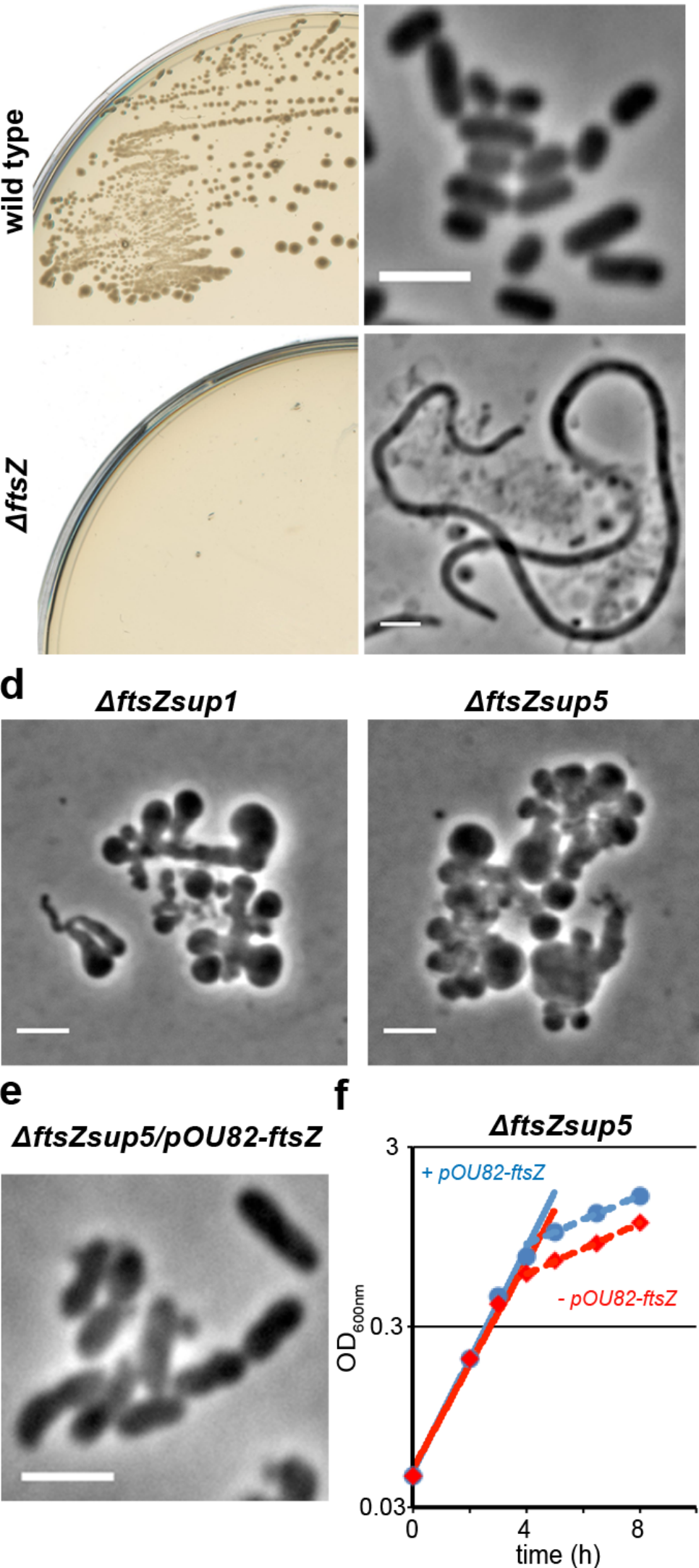

C
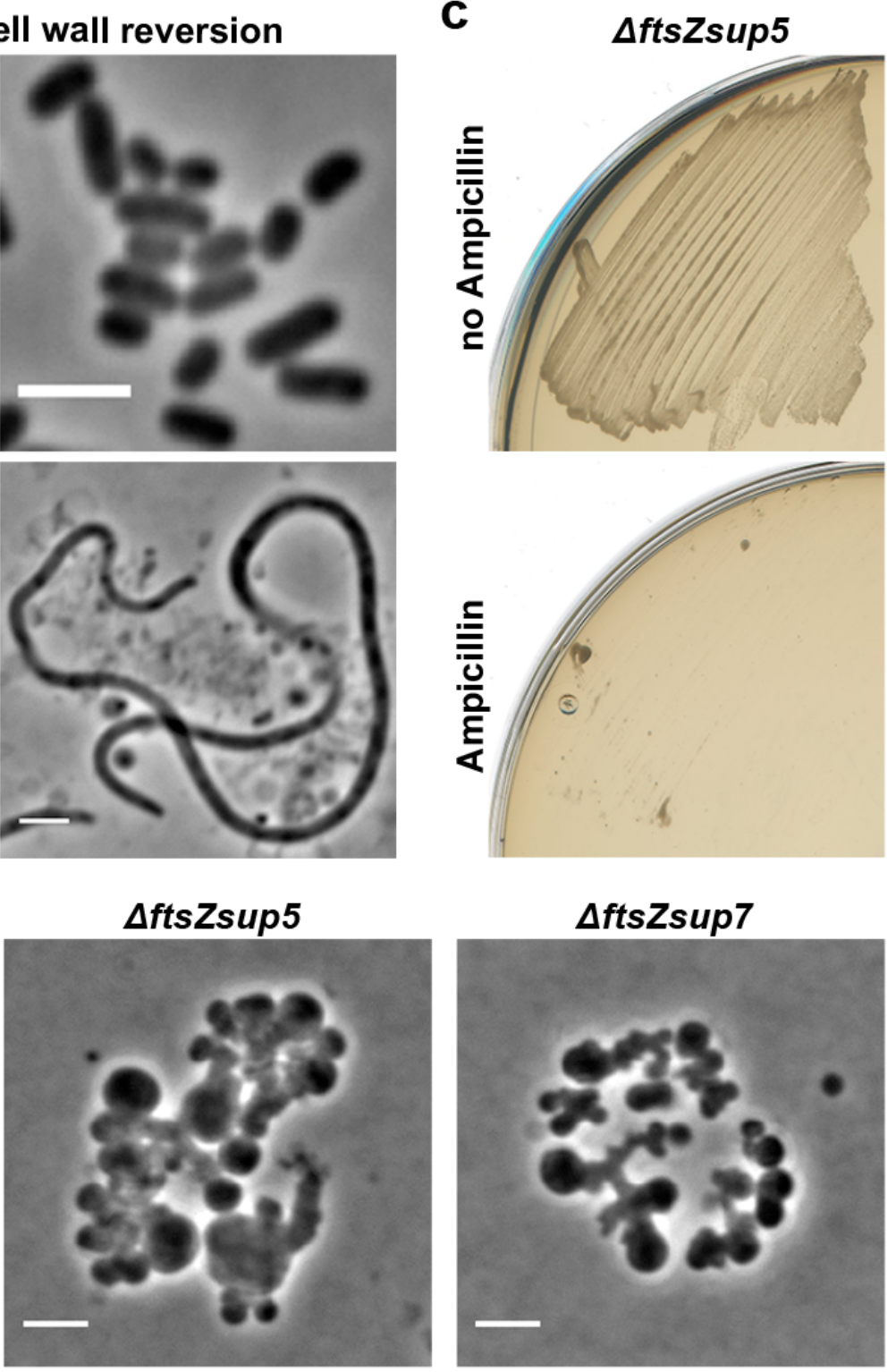

g

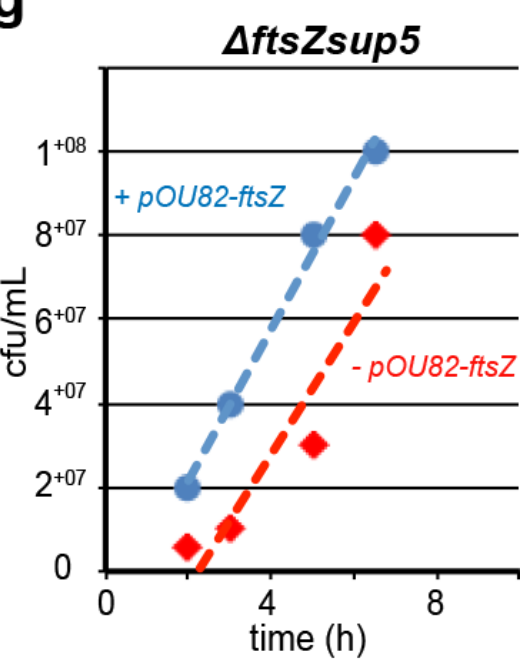




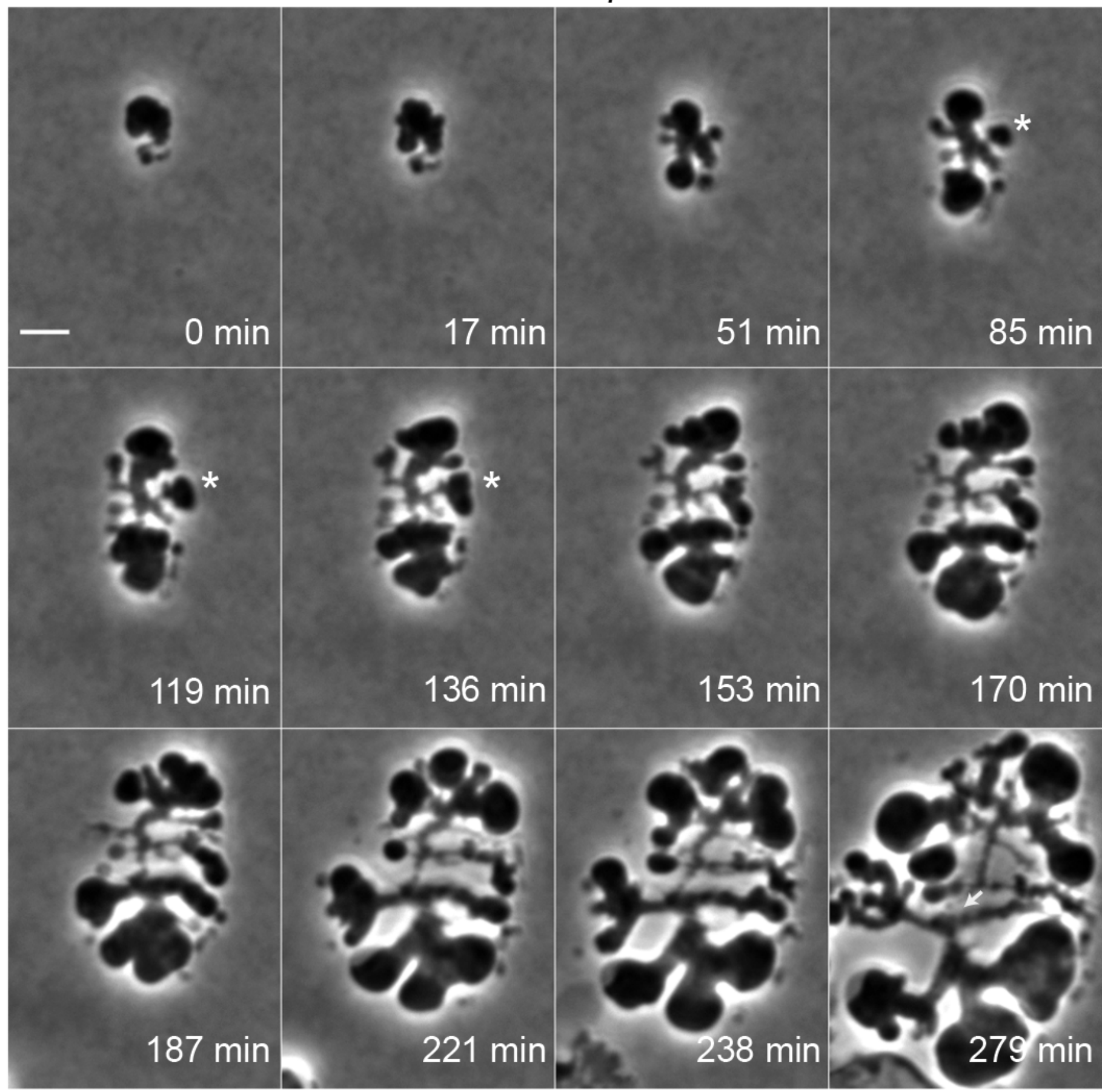

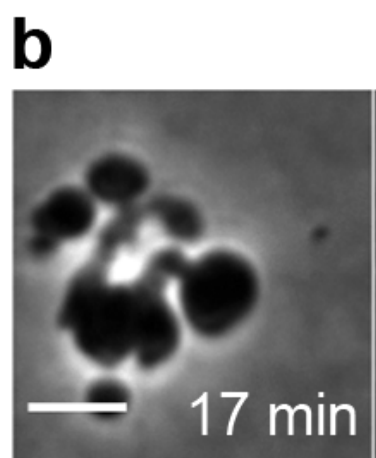

C

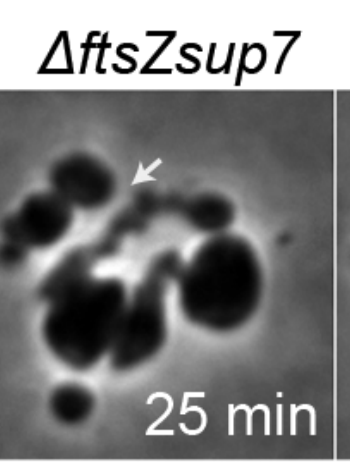

\section{$\Delta$ ftsZsup7}

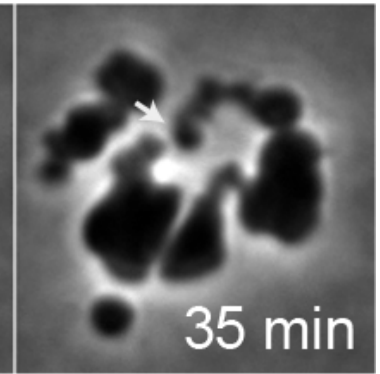

35 min

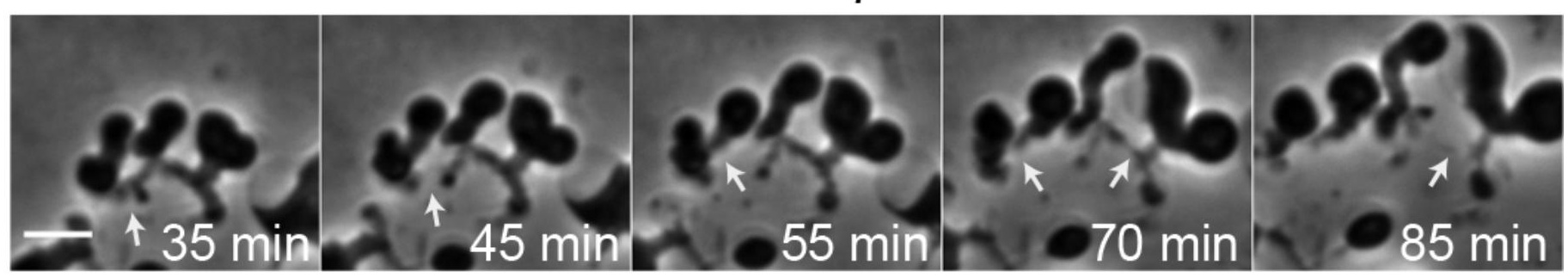


Rods to CFL transition

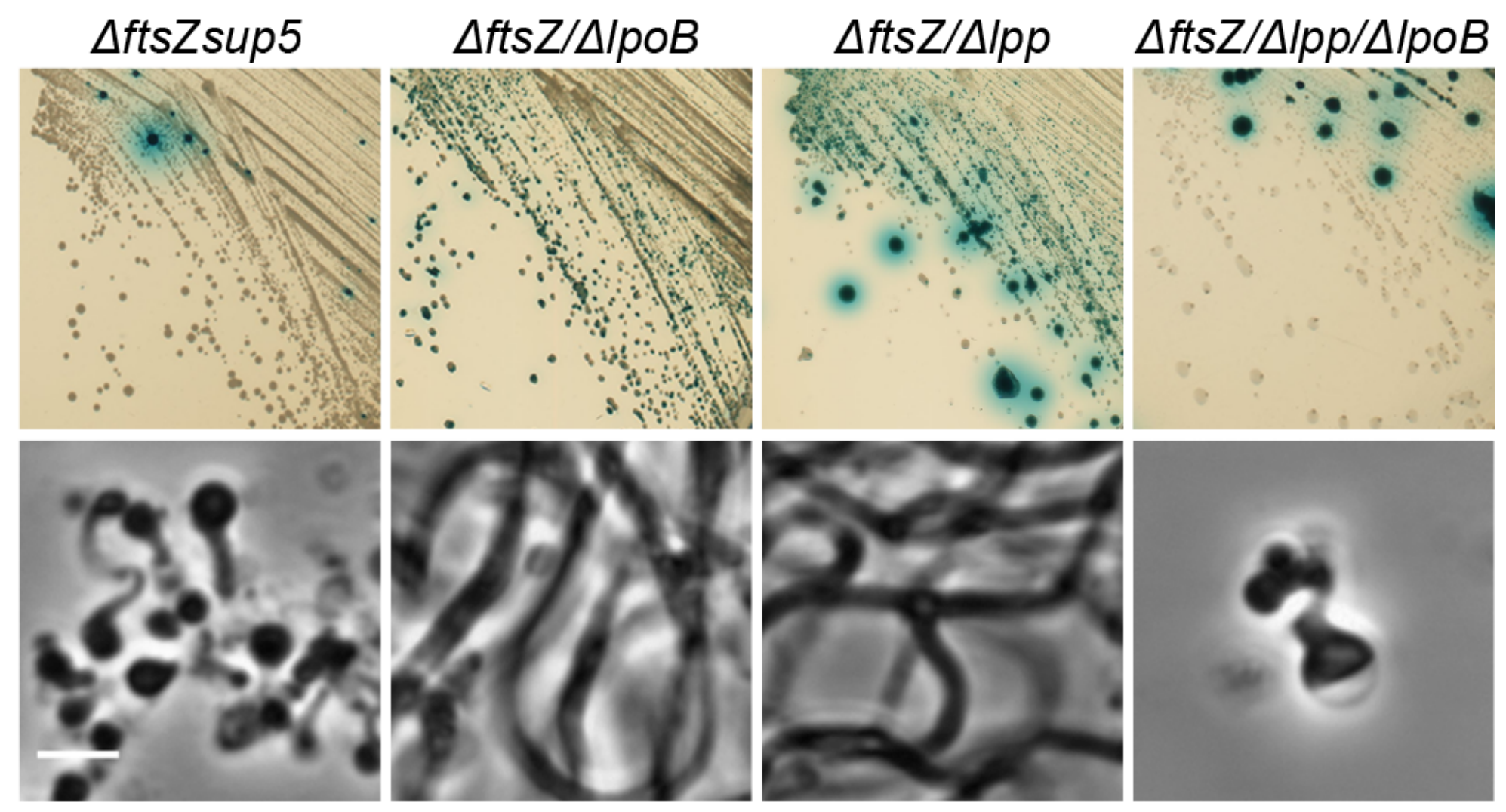

b

L-forms to CFL transition
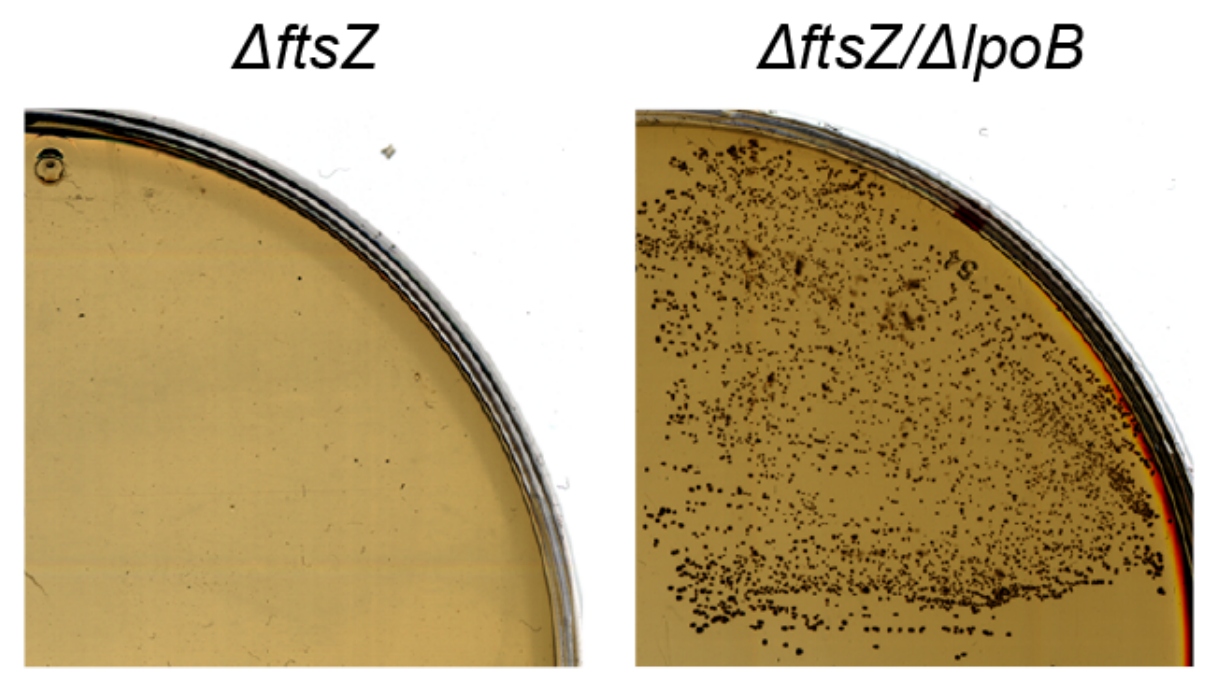

$\Delta f t s Z / \Delta / p p$

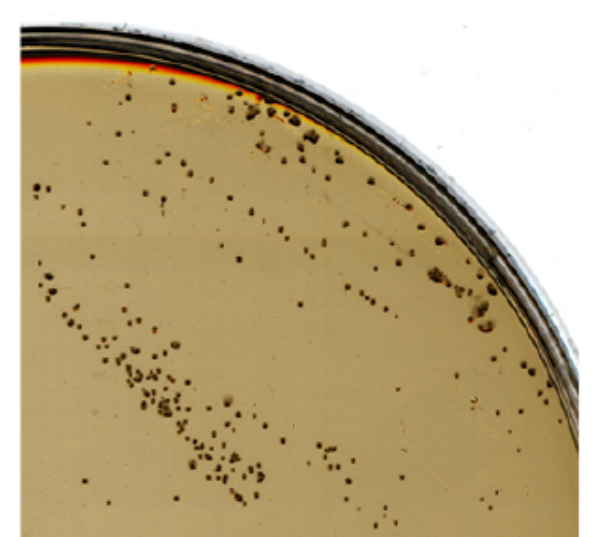

$\Delta f t s Z / \Delta / p \circ A$

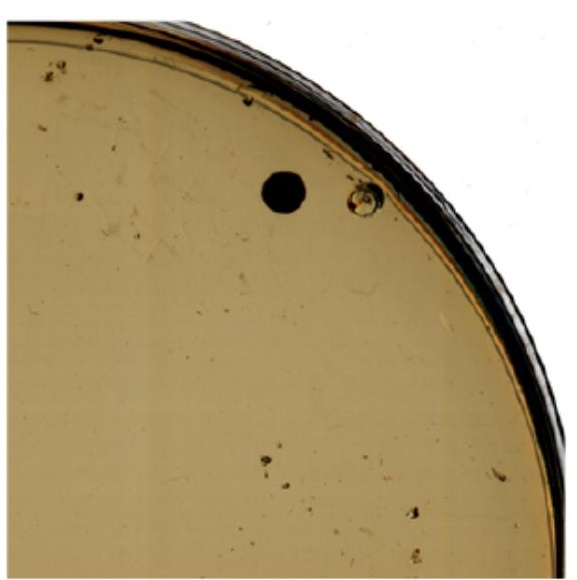

$\Delta f t s Z / \Delta m r c B$

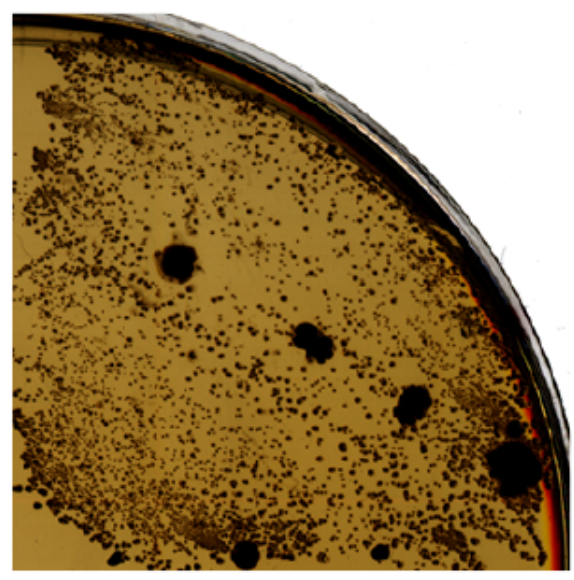

$\Delta f t s Z / \Delta m r c A$ 
a

$\Delta f t s Z / \Delta / p p / \Delta / p o B_{\text {sup }}+p B A D 33-/ p o B$

$-I p o B$

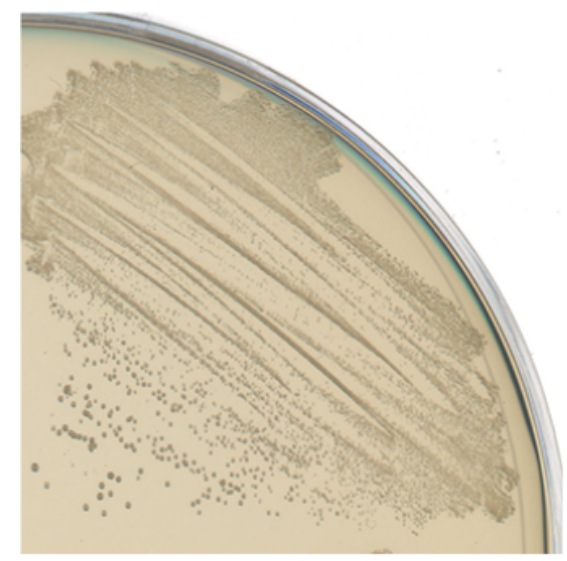

C

$\Delta f t s Z \sup 5(\Delta / p p / \Delta m r c B)+p B A D 33-m r c B$

$-m r c B$

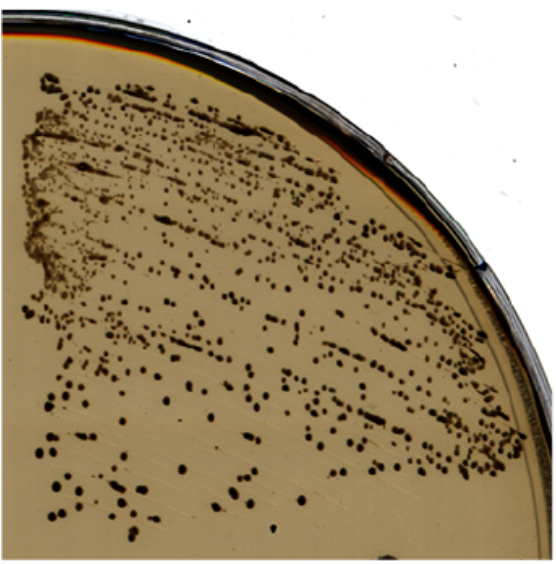

$+/ p o B$

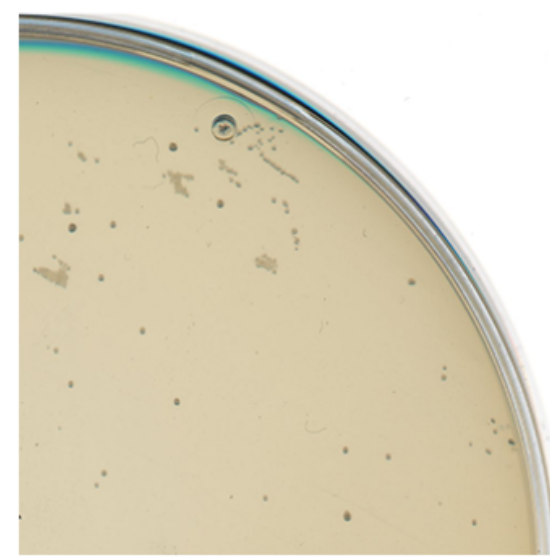

d $+m r c B$

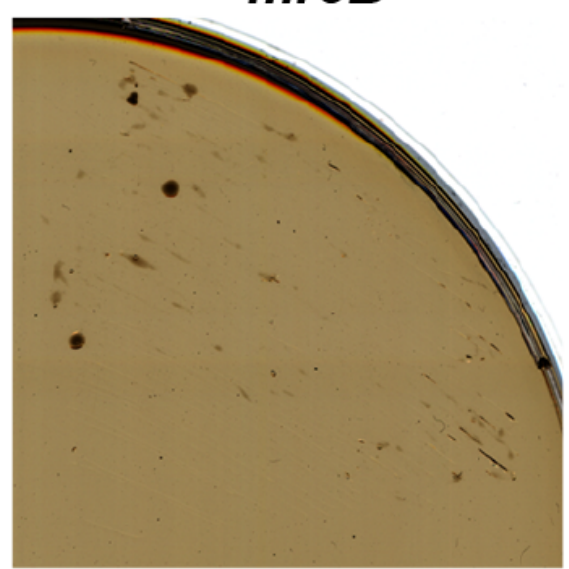

b $\quad \Delta f t s Z / \Delta l p p / \Delta / p o B_{\text {sup }}$ pBAD33-IpoB $+/ p o B$

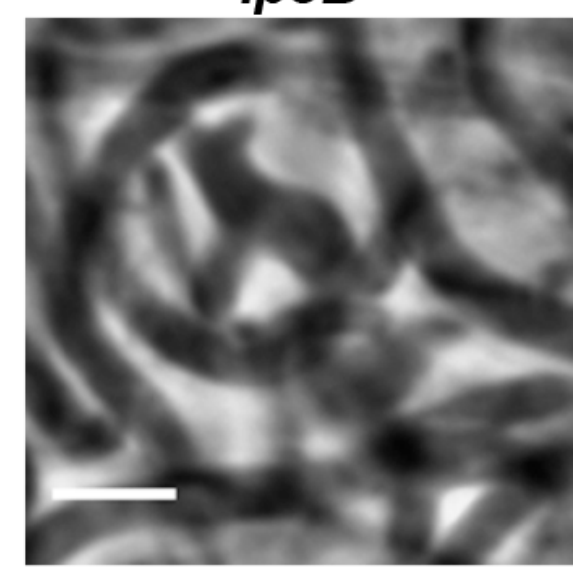

d

$\Delta$ ftsZsup5

$(\Delta / p p / \Delta m r c B)$

$+p B A D 33-m r c B$

$+m r c B$

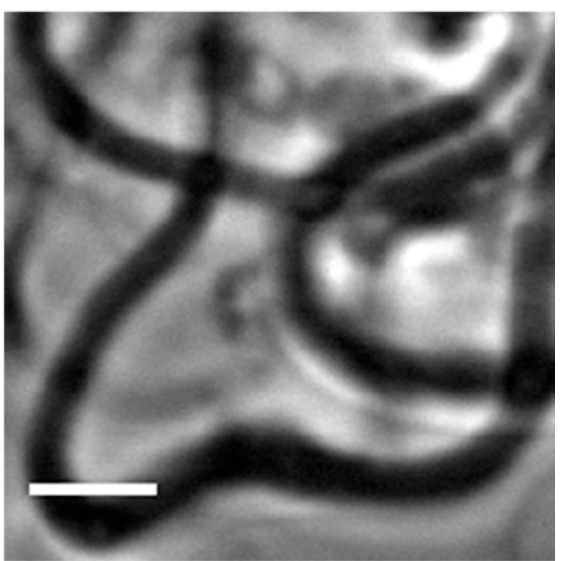

e

$\Delta f t s Z / I p p / / p o B_{\text {sup }}+p B A D 33-I p o B$

$+/ p o B$

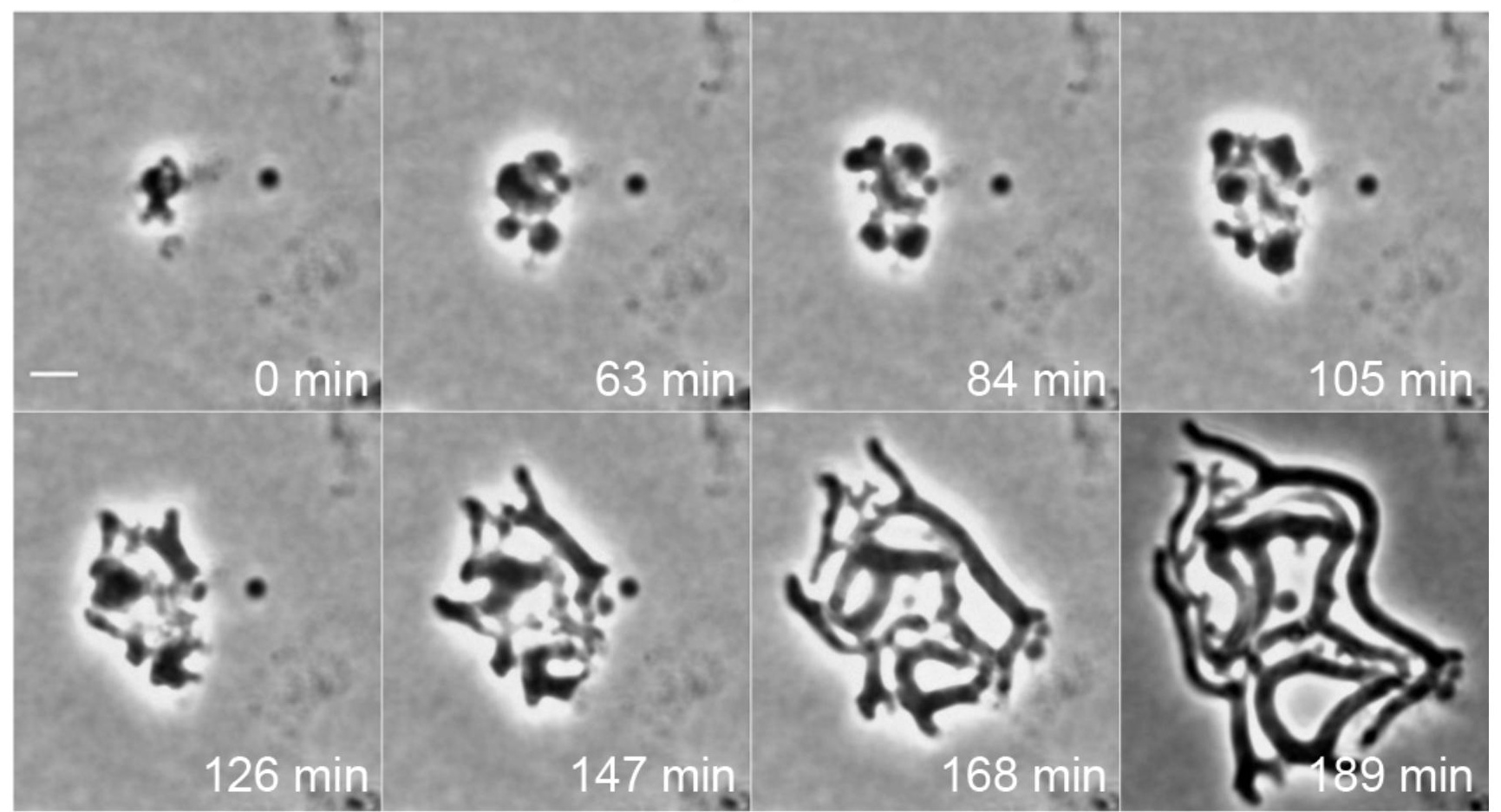




\section{Supplementary Information}

\section{Supplementary Data}

\section{Supplementary Data 1: Spontaneous mutations arise in CFL selective conditions}

5 It appears that secondary mutations frequently arise in CFL selective conditions, presumably

6 to improve the efficiency of growth. We sequenced a variant of the $\Delta f t s Z / \Delta / p p / \Delta / p o B$ strain

7 that showed improved growth, giving a mass doubling time of $60 \mathrm{~min}$, similar to that of the 8 original ftsZsup strains (Supplementary Fig. $4 \mathrm{c}-\mathrm{d}, \Delta f t s Z / \Delta / p p / \Delta / p o B_{\text {sup }}$ ). As for the original

9 CFL mutants, we found a mutation affecting colanic acid synthesis (truncation of the wzxC 10 and wcaJ genes; Supplementary Table 2). It therefore seems that synthesis of colanic acid 11 directly or indirectly impairs the growth of these complex suppressed strains, for reasons that 12 we have not yet determined. It is interesting to note that colanic acid is normally made under 13 stress conditions ${ }^{1}$ and that mutations affecting colanic acid synthesis have been found in at 14 least one well characterised L-form strain ${ }^{2}$.

Supplementary Data 2: Effects of the overexpression of Lpp in the $\Delta f t s Z / \Delta / p p / \Delta / p o B_{\text {sup }}$ strain on SDS sensitivity and on CFL proliferation

18 We firstly tested if the levels of Ipp expression from plasmids pBAD33 (pACYC184) or 19 pBAD24 (pBR322) were sufficient to complement the known sensitivity of an Ipp mutant to 20 SDS (Supplementary Fig 5a). As shown in Supplementary Fig 5b, in the presence of the Ipp 21 inducer arabinose the plasmid pBAD24-Ipp, but not pBAD33-Ipp, can complement the sensitivity to $0.5 \%$ SDS of the $\Delta \mathrm{ftsZ} / \Delta \mathrm{lpp} / \Delta \mathrm{poBsup}(\mathrm{FtsZ}+)$ strain, suggesting that the level

23 of Ipp expression from pBAD24 was sufficient to complement an Ipp mutation. We have 24 secondly transformed both plasmids, pBAD33-Ipp and pBAD24-Ipp, into the CFL (FtsZ) $25 \Delta f t s Z s u p 5$ and/or $\Delta f t s Z / \Delta / p p / \Delta / p o B_{\text {sup }}$ strains. As shown in Supplementary Fig $5 \mathrm{c}$ to $\mathrm{h}$, no 26 effect on CFL growth or morphology was observed upon induction of Ipp expression 27 (Arabinose). 


\section{Supplementary Data 3: Cell wall elongation system is required for CFL growth} We anticipated that the cell wall elongation system would be required for CFL growth,

31 and indeed, as shown in Supplementary Fig 7a-b (right panels), inhibition of MreB or PBP2

32 function with specifically targeted antibiotics (A22 and mecillinam, respectively) blocked CFL

33 proliferation. Controls showed that growth inhibition by these antibiotics could be restored by 34 overexpression of ftsQAZ (ftsZup), as described previously ${ }^{3}$. Finally, we also tested 35 inhibition of PBP3 activity. Surprisingly, given that this protein is part of the ftsZ-dependent 36 division machinery ${ }^{4}$, this resulted in loss of CFL proliferation (Supplementary Fig. 7c), for 37 reasons that are not yet clear. 
40

41

42

44

45

46

47

48

49

50

51

52

53

54

55

56

57

58

59

60

61

62

63

64

65

66

67

68

69

70

71

72

73

74

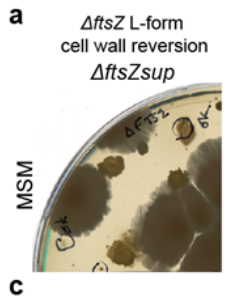

c

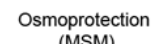
(MSM)
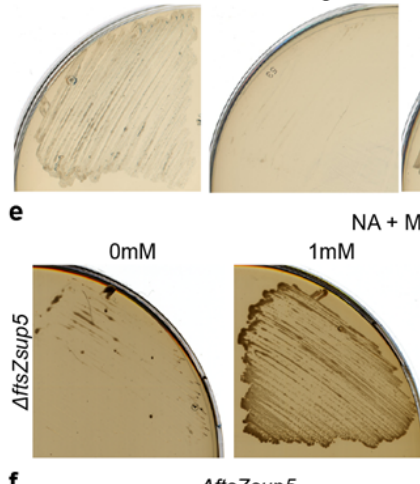

$\mathrm{NA}+$ Magnesium
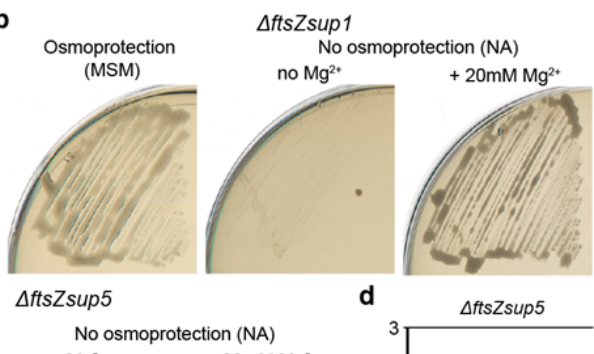

$\begin{array}{ll}\text { no } \mathrm{Mg}^{2+} & +20 \mathrm{mM} \mathrm{Mg}^{2+}\end{array}$

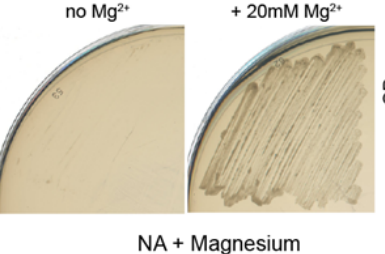

d $\quad \Delta t$ ts Zsup5
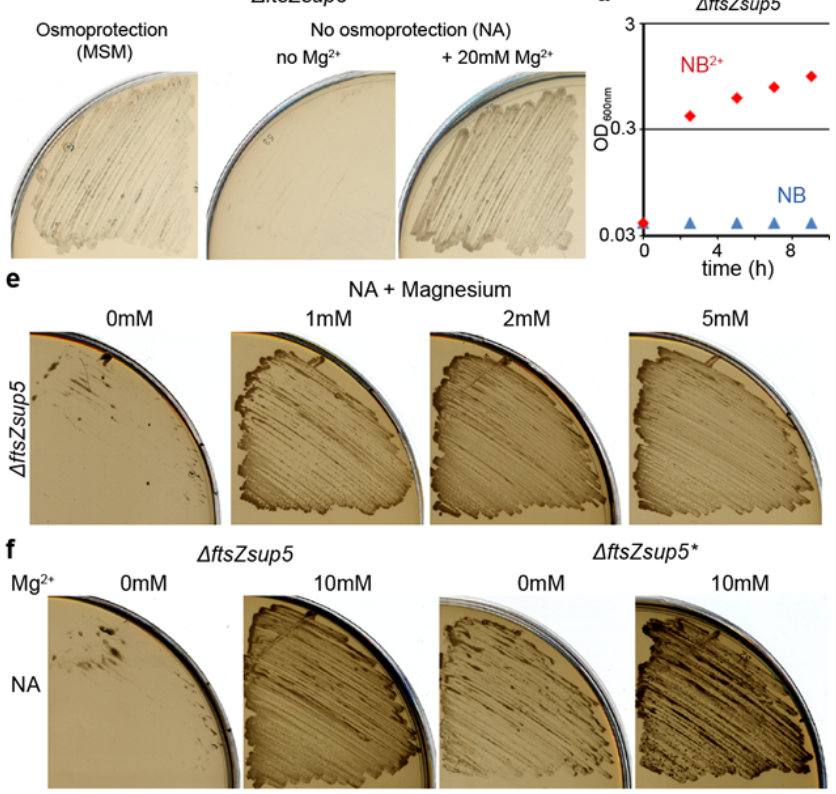

g

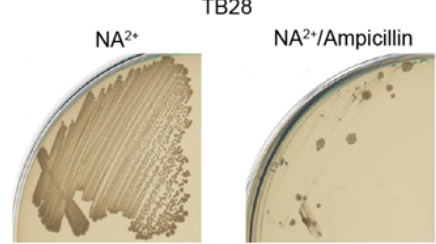

Supplementary Figure 1: Characterisation of walled E. coli ftsZ-less strains

a, Cell wall reversion of $E$. coli L-form strain RM349 ( $\Delta f t s Z)$, upon removal of the PG precursor synthesis inhibitor fosfomycin, on L-form-supporting medium (NA + MSM) plates after two weeks at $30^{\circ} \mathrm{C}$.

b-c, Growth of the strain $\Delta f t s Z s u p 1$ (b) and $\Delta f t s Z s u p 5$ (c) streaked on L-form-supporting medium (NA + MSM, left) or NA in the absence (no $\mathrm{Mg}^{2+}$, middle) or presence $\left(20 \mathrm{mM} \mathrm{Mg}^{2+}\right.$, right) of $20 \mathrm{mM}$ magnesium.

d, Growth profile of the strain $\Delta f t s Z s u p 5$ in NB in the presence (red, $\mathrm{NB}^{2+}$ ) or absence (blue,

$3 \mathrm{NB}$ ) of $20 \mathrm{mM} \mathrm{Mg}^{2+}$.

4 e, Growth of the strain $\Delta$ ftsZsup5 streaked on NA plates with various concentration of $\mathrm{Mg}^{2+}$. 
f. Growth of the strain $\triangle f t s Z s u p 5$ (left panels) and $\Delta f t s Z s u p 5^{*}$, magnesium dependant 76 suppressor (right panels) streaked on NA plates in absence $(0 \mathrm{mM})$ or presence $(10 \mathrm{mM})$ of $7710 \mathrm{mM}$ magnesium.

$78 \mathrm{~g}$, Growth of the strain wild type TB28 streaked on NA $+20 \mathrm{mM} \mathrm{Mg}^{2+}$ plates with $79 \quad\left(\mathrm{NA}^{2+} /\right.$ Ampicillin) or without $\left(\mathrm{NA}^{2+}\right) 10 \mu \mathrm{g} / \mathrm{ml}$ of Ampicillin.

80

81

82

83

84

85

86

87

88

89

90

91

92

93

94

95

96

Supplementary Figure 2: Nucleoid localisation in an E. coli ftsZ-less strain

97 Phase contrast (Phase, left) and fluorescence (DAPI, middle) microscopy of $\triangle$ ftsZsup5 cells 98 grown in NB with $\mathrm{Mg}^{2+}$ and stained with DAPI. Overlay (right) represents the merge of phase 99 and fluorescent images. Scale bar, $3 \mu \mathrm{m}$. 
117 a, Growth of the strain $\Delta f t s Z s u p 5$, after reintroduction of the plasmid pOU82-ftsZ, streaked 118 on NA + $20 \mathrm{mM} \mathrm{Mg}^{2+}$ plate, containing X-gal to show the presence of the plasmid.

119 b, Multiplex PCR of the ftsK, murA, ftsZ and mreC genes from genomic DNA of the E. coli 120 strains $\Delta f t s Z$ pOU82-ftsZ (1), $\Delta f t s Z s u p 1$ (2), $\Delta$ ftsZsup5 (3) and $\Delta f t s Z s u p 5$ pOU82-ftsZ (4). M 121 represents the DNA ladder.

122 c, Growth of the strain $\Delta f t s Z s u p 5$, streaked on NA with no added magnesium with (right) or 123 without (left) the plasmid pOU82-ftsZ.

$124 \mathrm{~d}$, Phase contrast microscopy of the $\Delta$ ftsZ cells, carrying the plasmid pOU82-ftsZ, grown in $125 \mathrm{NB}$ with $20 \mathrm{mM} \mathrm{Mg}^{2+}$. Scale bar, $3 \mu \mathrm{m}$. 
Supplementary Figure 4: Loss of Lpp and PBP1B activities promotes an ftsZ-less but

b

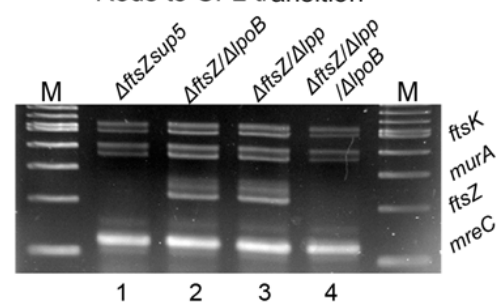
Rods to CFL transition

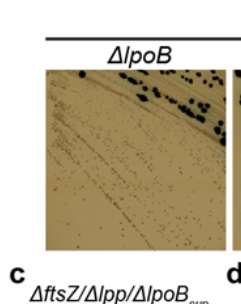

$\Delta f t s Z \Delta / p p$
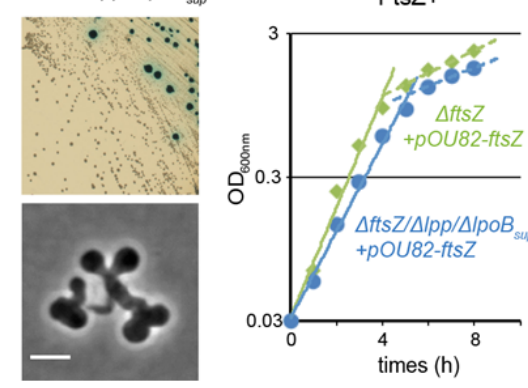

e

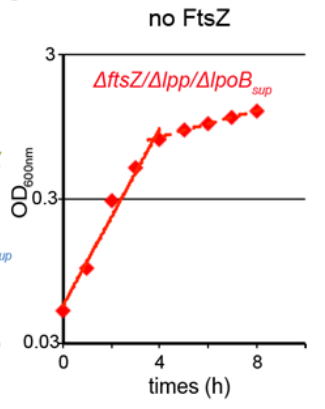
walled mode of proliferation.

a, Multiplex PCR of the ftsK, murA, ftsZ and mreC genes from genomic DNA of the $E$. coli strains $\Delta f t s Z s u p 5$ (1), $\Delta f t s Z / \Delta / p p(2), \Delta f t s Z / \Delta / p o B(3)$ and $\Delta f t s Z / \Delta / p p / \Delta / p o B(4)$ obtained from the plates in Figure 3a. M represents the DNA ladder. $(\Delta f t s Z / \Delta / p p / \Delta / p o A), R M 449$ ( $\Delta f t s Z / \Delta / p p / \Delta m r c A)$ strains, containing the plasmids pOU82-ftsZ and pKG339, streaked on NA containing $20 \mathrm{mM} \mathrm{Mg}^{2+}$, Tetracycline, IPTG and Xgal. c, ftsZ loss assay (top) of RM447 ( $\left.\Delta \mathrm{ftsZ} / \Delta / \mathrm{pp} / \Delta / \mathrm{poB}_{\text {sup }}\right)$ strain, containing the plasmids pOU82-ftsZ and pKG339, streaked on NA containing $20 \mathrm{mM} \mathrm{Mg}^{2+}$, Tetracycline, IPTG and Xgal. Corresponding cell morphology (bottom) of the streaked strain was visualised by phase contrast microscopy. Scale bar, $3 \mu \mathrm{m}$.

d, Growth profile of strains RM349 ( $\triangle \mathrm{ftsZ}$ pOU82-ftsZ, green) and RM447 ( $\Delta f t s Z / \Delta / p p / \Delta / p o B_{\text {sup }}$ pOU82-ftsZ, blue) in NB containing $20 \mathrm{mM} \mathrm{Mg}^{2+}$. The mass doubling times calculated for strains RM349 and RM447 were about 47 and $58 \mathrm{~min}$, respectively. e, Growth profile of the strain RM445 ( $\left.\Delta \mathrm{ftsZ} / \Delta / \mathrm{pp} / \Delta / \mathrm{poB}_{\text {sup }}\right)$ in NB with $20 \mathrm{mM} \mathrm{Mg}{ }^{2+}$. The 
164

165

166

167

168

169

170

171

172

173

174

175

176

177

178

179

180

181

182

183

184

185

186

187

188

189

190

191

192

193

194

195

196

197

198

199 a
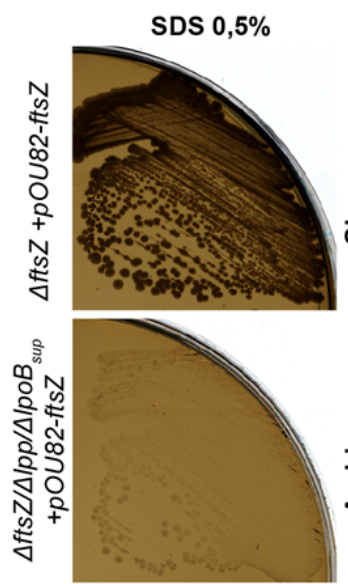

C

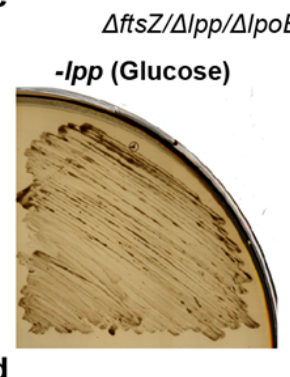

$\Delta f t s Z / \Delta / p p / \Delta / p o B_{\text {sup }}+p B A D 24-I p p$

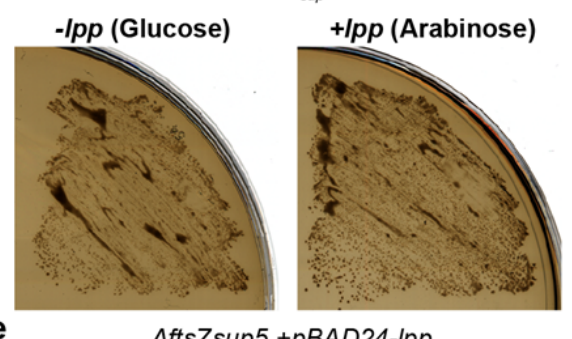

$\triangle$ ftsZsup5 +pBAD24-Ipp

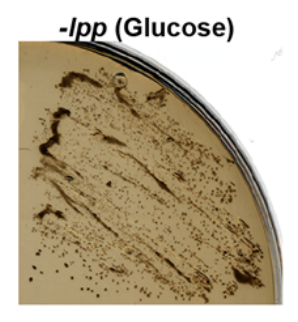

$\triangle$ ftsZsup5 + pBAD33-wcaJ
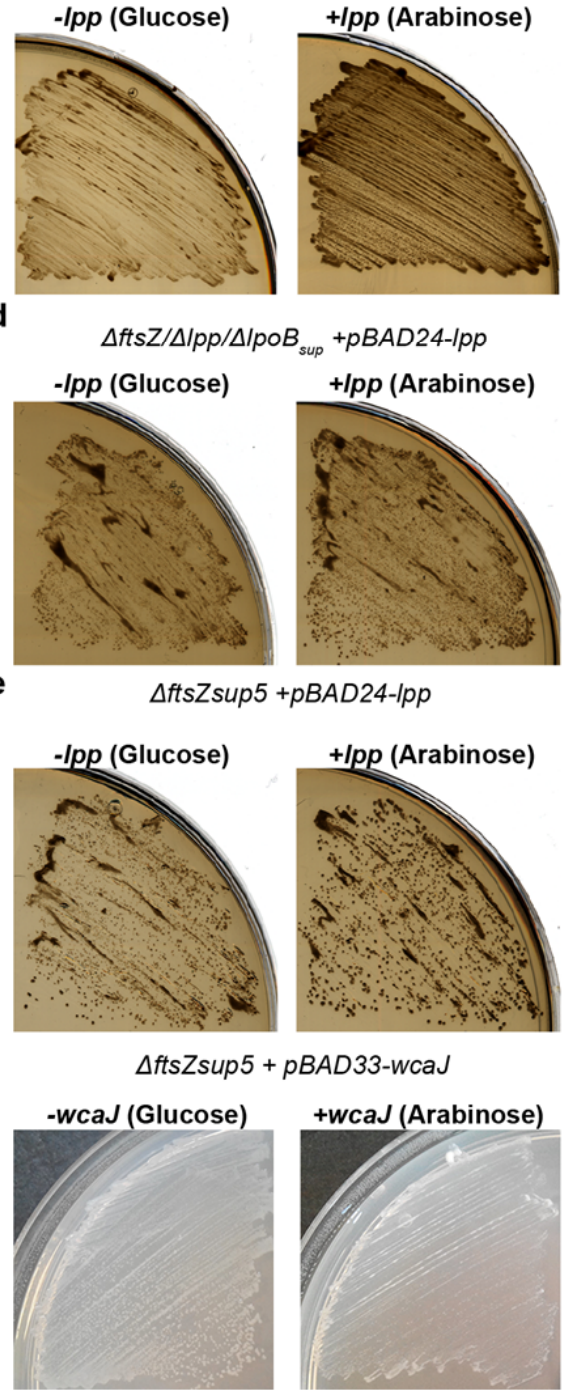

+wcaJ (Arabinose)

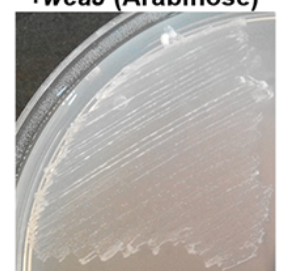

b $\quad \Delta f t s Z / \Delta / p p / \triangle 1 p 0 B_{\text {sup }}+p O U 82$-ftsZ

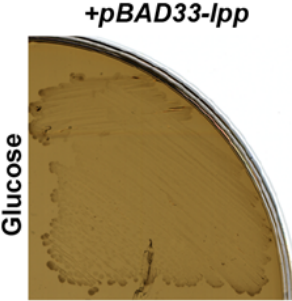

+pBAD24-Ipp
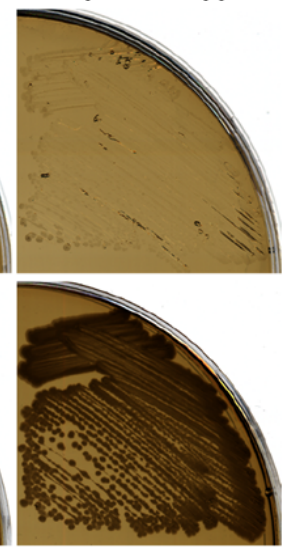

f $\Delta f t s Z / \Delta / p p / \Delta / p \circ B_{s u p}$ $+p B A D 33-1 p p$ +Ipp (Arabinose)

g $\triangle f t s Z / \Delta / p p / \Delta / p o B_{\text {sup }}$ $+p B A D 24-1 p p$ +lpp (Arabinose)

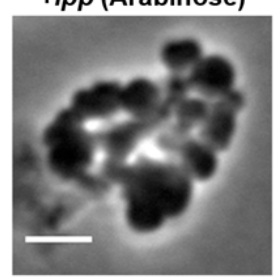

h $\quad \Delta f t s Z \sup 5$ $+p B A D 24-I p p$ +Ipp (Arabinose)

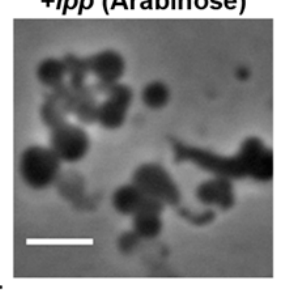

$\triangle$ ftsZsup5 $+p B A D 33-w c a J$ +wcaJ (Arabinose)

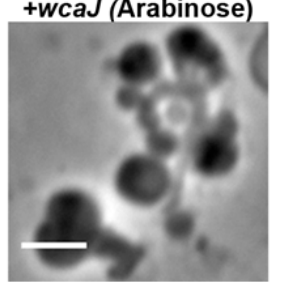


202 a, Growth of strains RM349 ( $\Delta f t s Z$ pOU82-ftsZ, top) and RM447 ( $\Delta f t s Z / \Delta / p p / \Delta / p o B_{\text {sup }}$ pOU82$203 \mathrm{ftsZ}$, bottom) streaked on NA $+20 \mathrm{mM} \mathrm{Mg}^{2+}$ in the presence of $0.5 \%$ SDS

204 b, Growth of the strain RM447 ( $\Delta f t s Z / \Delta / p p / \Delta / p o B_{\text {sup }}$ pOU82-ftsZ), carrying plasmids pBAD33205 Ipp (left) and pBAD24-Ipp (bottom) streaked on NA + $20 \mathrm{mM} \mathrm{Mg}^{2+}$ with $0.5 \% \mathrm{SDS}$, and with 206 Ipp expression repressed (glucose, top) or induced (arabinose, bottom).

207 c-e, Growth of strains RM445 ( $\Delta \mathrm{ftsZ} / \Delta / \mathrm{pp} / \Delta / \mathrm{poB}_{\text {sup }}$ ), carrying plasmids pBAD33-lpp (c) or 208 pBAD24-Ipp (d) and RM362 ( $\triangle$ ftsZsup5), carrying the plasmid pBAD24-Ipp (e), streaked on $209 \mathrm{NA}+20 \mathrm{mM} \mathrm{Mg}^{2+}$ with Ipp expression repressed (glucose, left) or induced (arabinose, right).

$210 \mathbf{f}-\mathbf{h}$, Corresponding phase contrast images of RM445 ( $\Delta \mathrm{ftsZ} / \Delta / p p / \Delta / p o B_{\text {sup }}$ ) pBAD33-lpp (f),

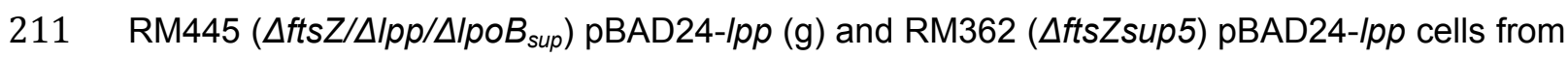
212 c-e, respectively, in the presence of inducer (arabinose).

213 i, Growth of strain RM362 ( $\Delta$ ftsZsup5), carrying the plasmid pBAD33-wcaJ, streaked on NA+ $21420 \mathrm{mM} \mathrm{Mg}^{2+}$ with wcaJ expression repressed (glucose) or induced (arabinose).

215 j, Phase contrast microscopy of RM362 cells ( $\Delta$ ftsZsup5), carrying pBAD33-wcaJ from panel 216 i in the presence of inducer (arabinose). Scale bar, $3 \mu \mathrm{m}$.

$+\mid p o B$
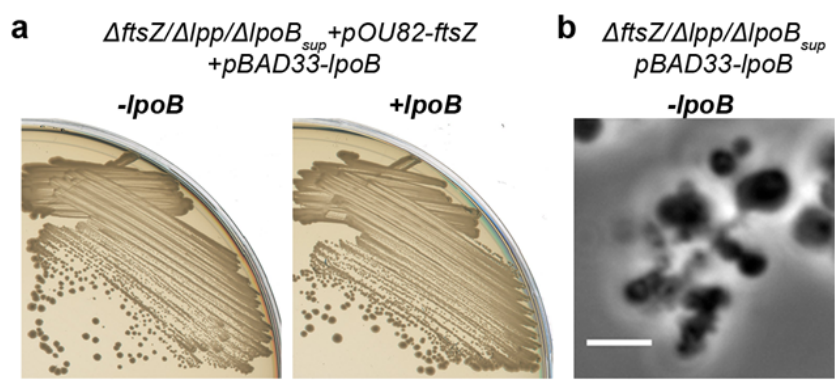

Supplementary Figure 6: PBP1B activity inhibits CFL proliferation in the absence of FtsZ

a, Growth of the strain RM445 ( $\left.\Delta \mathrm{ftsZ} / \Delta / p p / \Delta / p o B_{\text {sup }}\right)$ in presence of pOU82-ftsZ, carrying the plasmid pBAD33-IpoB, streaked on $\mathrm{NA}+20 \mathrm{mM} \mathrm{Mg}^{2+}$ in the absence (left) or presence (right) of the inducer of $I p o B$ expression (arabinose).

235 Scale bar, $3 \mu \mathrm{m}$. 


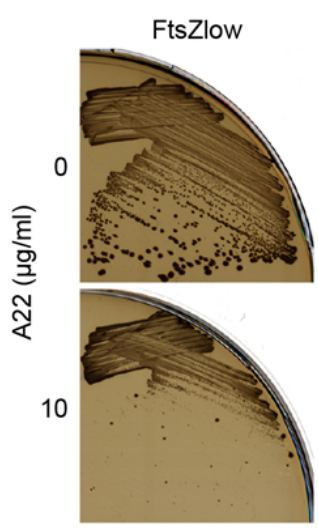
$\Delta f t s Z / \Delta / p p / \Delta / p o B_{\text {sup }}$

b
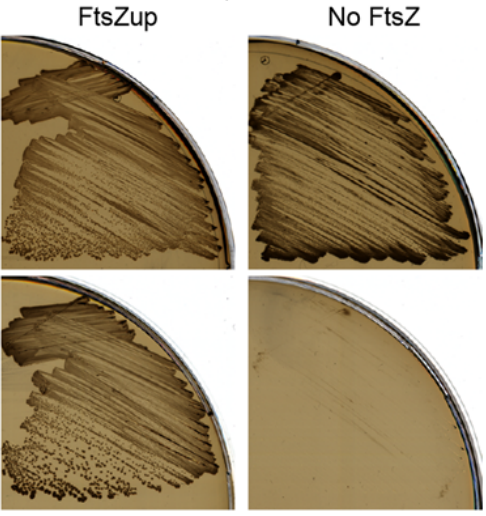

$\Delta f t s Z / \Delta / p p / \Delta / p o B_{\text {sup }}$

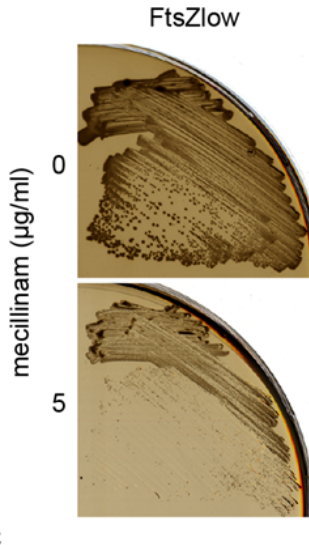

FtsZup
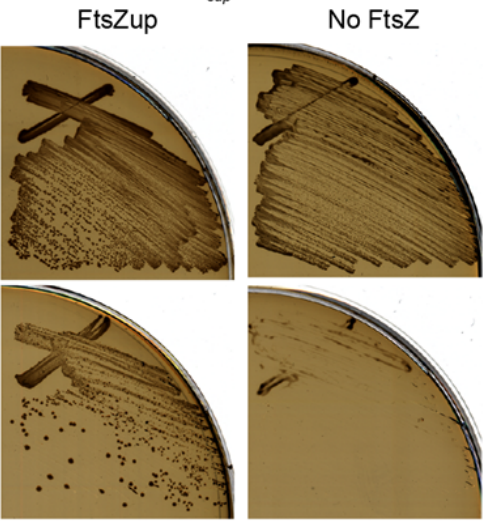

C with FtsZ

$\Delta f t s Z / \Delta / p p / \Delta / p o B_{\text {sup }}$

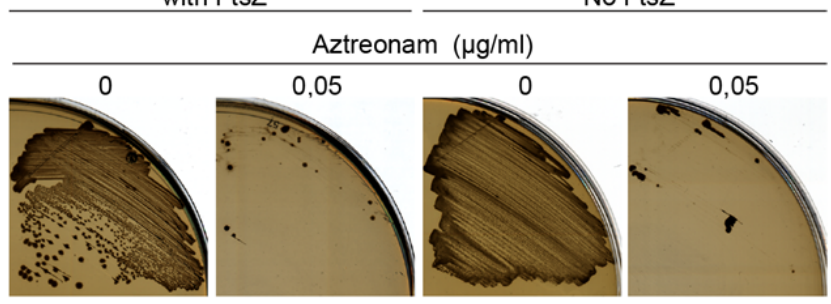

261 Supplementary Figure 7: Effect of the inhibition of MreB, PBP2 and PBP3 on CFL 262 proliferation

263 a, Growth of the strain RM445 ( $\Delta \mathrm{ftsZ} / \Delta / \mathrm{pp} / \Delta / \mathrm{poB}_{\text {sup }}$ ) carrying plasmids pOU82-ftsZ (FtsZlow, 264 left), pBS58 (FtsZup, middle) or none (No FtsZ, right), streaked on $\mathrm{NA}+20 \mathrm{mM} \mathrm{Mg}^{2+}$ in the 265 absence (top) or presence (bottom) of $10 \mu \mathrm{g} / \mathrm{ml}$ of A22.

$266 \mathrm{~b}$, As a, but with $5 \mu \mathrm{g} / \mathrm{ml}$ of mecillinam in bottom plates.

267 c, Growth of strain RM445 ( $\Delta \mathrm{ftsZ} / \Delta / \mathrm{pp} / \Delta / \mathrm{poB}_{\text {sup }}$ ) carrying the plasmid pOU82-ftsZ (with FtsZ, 268 left panels) or none (No FtsZ, right panels), streaked on NA $+20 \mathrm{mM} \mathrm{Mg}^{2+}$ in the absence (0) 269 or presence $(0.05)$ of $0.05 \mu \mathrm{g} / \mathrm{ml}$ of aztreonam. 


\section{Supplementary Tables}

\section{Supplementary Table 1: Genetic variation in fts $_{\text {sup }}$ strains}

\begin{tabular}{|c|c|c|c|c|c|}
\hline & $\begin{array}{c}\text { Base } \\
\text { Position }^{\mathrm{a}}(\mathrm{bp}) \\
\end{array}$ & $\begin{array}{l}\text { Genetic } \\
\text { Variation } \\
\end{array}$ & $\begin{array}{c}\text { Gene name } \\
\text { (synonym) }\end{array}$ & Type of Mutation & Gene function $^{\mathrm{b}}$ \\
\hline \multirow{5}{*}{ 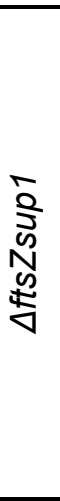 } & $105305-106456$ & Deletion & ftsZ & $\begin{array}{l}\text { Deletion of the } \\
\text { gene } \mathrm{fts} Z{ }^{6}\end{array}$ & $\begin{array}{l}\text { GTP-binding tubulin-like cell division } \\
\text { protein }\end{array}$ \\
\hline & $\begin{array}{l}1161341- \\
1161903\end{array}$ & $\begin{array}{l}\text { Deletion of } \\
562 \mathrm{pb}\end{array}$ & fhuE-hinT & $\begin{array}{l}\text { promoter region of } \\
\text { the operon } \\
\text { containing IpoB }\end{array}$ & $\begin{array}{l}\text { IpoB: Outer membrane lipoprotein } \\
\text { - activator of PBP1B activity }\end{array}$ \\
\hline & 2824993 & A to $G$ & $m / t B$ & Missense E195G & $\begin{array}{c}\text { Membrane-bound lytic murein } \\
\text { transglycosylase B }\end{array}$ \\
\hline & 3080013 & $\mathrm{~T}$ to $\mathrm{G}$ & tktA & $\begin{array}{l}\text { Nonsense } \\
\text { Y541Stop }\end{array}$ & Transketolase I \\
\hline & 3969949 & $\mathrm{~T}$ to $\mathrm{G}$ & $w z z E$ & Missense Y307D & $\begin{array}{c}\text { Enterobacterial Common Antigen } \\
\text { polysaccharide } \\
\text { chain length modulation protein }\end{array}$ \\
\hline \multirow{7}{*}{ 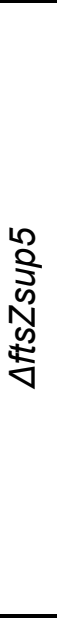 } & $105305-106456$ & Deletion & ftsZ & $\begin{array}{l}\text { Deletion of the } \\
\text { gene } \mathrm{fts}^{6}\end{array}$ & $\begin{array}{c}\text { GTP-binding tubulin-like cell division } \\
\text { protein }\end{array}$ \\
\hline & 165768 & $\mathrm{C}$ to $\mathrm{T}$ & $m r c B$ & Nonsense 347Stop & Penicillin-binding protein 1B (Pbp1B) \\
\hline & $\begin{array}{l}1404427- \\
1585557\end{array}$ & $\begin{array}{l}\text { Deletion of } \\
181 \mathrm{~kb}\end{array}$ & $a b g A-y d e P$ & $\begin{array}{l}\text { Multiple gene } \\
\text { deletions }\end{array}$ & \\
\hline & $\begin{array}{l}1757618- \\
1757619\end{array}$ & $\begin{array}{l}\text { Deletion of a } \\
\text { dinucleotides } \\
\text { (CC) }\end{array}$ & Ipp & Nonsense 74Stop & Murein lipoprotein (Braun's lipoprotein) \\
\hline & 2121458 & $\begin{array}{c}\text { Deletion of a } \\
\text { nucleotide }(C)\end{array}$ & wcaJ & Nonsense 53Stop & $\begin{array}{c}\text { Colanic acid biosynthsis UDP-glucose } \\
\text { lipid } \\
\text { carrier transferase }\end{array}$ \\
\hline & 2137438 & $\mathrm{G}$ to $\mathrm{A}$ & $\begin{array}{l}\text { intergenic } \\
\quad \text { of } \\
\text { wza-yegH }\end{array}$ & n.a & \\
\hline & 3802322 & $\mathrm{~T}$ to $\mathrm{A}$ & $\begin{array}{l}\text { waaO } \\
\text { (waal) }\end{array}$ & Missense N246I & $\begin{array}{c}\text { UDP-D-glucose:(glucosyl)LPS } \\
\alpha-1,3 \text {-glucosyltransferase }\end{array}$ \\
\hline \multirow{8}{*}{\begin{tabular}{l}
$\hat{2}$ \\
\multirow{2}{5}{} \\
N \\
\multirow{2}{*}{} \\
\multirow{2}{*}{}
\end{tabular}} & $105305-106456$ & Deletion & ftsZ & $\begin{array}{l}\text { Deletion of the } \\
\text { gene } \mathrm{fts}^{6}\end{array}$ & $\begin{array}{l}\text { GTP-binding tubulin-like cell division } \\
\text { protein }\end{array}$ \\
\hline & $\begin{array}{l}1162915- \\
1165932\end{array}$ & Deletion of $3 \mathrm{~kb}$ & $\begin{array}{l}\text { IpoB- } \\
\text { intergenic } \\
\text { of ycfP-ndh }\end{array}$ & $\begin{array}{l}\text { Multiple gene } \\
\text { deletions } \\
\text { containing IpoB }\end{array}$ & $\begin{array}{l}\text { IpoB: Outer membrane lipoprotein } \\
\text { - activator of PBP1B activity }\end{array}$ \\
\hline & $\begin{array}{l}1391013- \\
1589070\end{array}$ & $\begin{array}{l}\text { Deletion of } \\
198 \mathrm{~kb}\end{array}$ & ycjY-ydeT & $\begin{array}{l}\text { Multiple gene } \\
\text { deletions } \\
\text { (Rac prophage) }\end{array}$ & \\
\hline & $\begin{array}{l}1750679- \\
1761439\end{array}$ & $\begin{array}{l}\text { Deletion of } \\
11 \mathrm{~kb}\end{array}$ & ydhX-sufD & $\begin{array}{l}\text { Deletion containing } \\
\text { the gene Ipp }\end{array}$ & $\begin{array}{l}\text { Ipp: Murein lipoprotein (Braun's } \\
\text { lipoprotein) }\end{array}$ \\
\hline & 2137438 & $G$ to $A$ & $\begin{array}{l}\text { intergenic } \\
\quad \text { of } \\
\text { wza-yegH }\end{array}$ & n.a & \\
\hline & 2202729 & $\mathrm{~T}$ to $\mathrm{C}$ & yehl & Silent & Conserved hypothetical protein \\
\hline & 3802322 & $\mathrm{~T}$ to $\mathrm{A}$ & $\begin{array}{l}\text { waaO } \\
\text { (waal) }\end{array}$ & Missense N246I & $\begin{array}{l}\text { UDP-D-glucose:(glucosyl)LPS } \\
\text { a-1,3-glucosyltransferase } \\
\text { Enterobacterial Common Antigen }\end{array}$ \\
\hline & 3969793 & $\mathrm{G}$ to $\mathrm{T}$ & $w z z E$ & Nonsense 255Stop & $\begin{array}{c}\text { polysaccharide } \\
\text { chain length modulation protein }\end{array}$ \\
\hline
\end{tabular}

${ }^{a}$ Coordinate is based on NCBI RefSeq NC_000913.3 E. coli MG1655 Genome; ${ }^{0}$ Gene function is based on EcoCyc Database; Red and Green colors represent genes respectively involved in peptidoglycan and extracellular polysaccharides synthesis

273 
275 Supplementary Table 2: Genetic variation in the $\Delta f t s Z / \Delta / p p / \Delta / p o B_{\text {sup }}$ strain

\begin{tabular}{|c|c|c|c|c|c|}
\hline & $\begin{array}{c}\text { Base } \\
\text { Position }^{a} \text { (bp) } \\
\end{array}$ & $\begin{array}{c}\text { Genetic } \\
\text { Variation } \\
\end{array}$ & $\begin{array}{c}\text { Gene name } \\
\text { (synonym) }\end{array}$ & Type of Mutation & Gene function ${ }^{b}$ \\
\hline \multirow{9}{*}{ 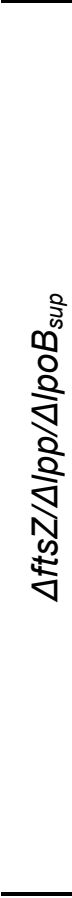 } & 458026 & $G$ to $A$ & $\operatorname{clpX}$ & Missense D201N & $\begin{array}{l}\text { ATP-dependent serine } \\
\text { protease }\end{array}$ \\
\hline & $105305-106456$ & Deletion & $f t s Z$ & Deletion of the gene ${ }_{6} t s Z$ & $\begin{array}{l}\text { GTP-binding tubulin-like cell } \\
\text { division protein }\end{array}$ \\
\hline & $\begin{array}{l}1162638- \\
1163279\end{array}$ & Deletion & IpoB & $\begin{array}{l}\text { Deletion of the gene } \\
\qquad / p o B^{7}\end{array}$ & $\begin{array}{l}\text { Outer membrane lipoprotein - } \\
\text { activator of PBP1B activity }\end{array}$ \\
\hline & $\begin{array}{l}1405207- \\
1589365\end{array}$ & $\begin{array}{l}\text { Deletion of } \\
184 \mathrm{~kb}\end{array}$ & abgR-ydeT & Multiple gene deletions & \\
\hline & $\begin{array}{l}1757421- \\
1757657\end{array}$ & Deletion & Ipp & Deletion of the gene Ipp & $\begin{array}{c}\text { Murein lipoprotein (Braun's } \\
\text { lipoprotein) }\end{array}$ \\
\hline & $\begin{array}{l}2120046- \\
2120848\end{array}$ & $\begin{array}{l}\text { Deletion of } \\
802 p b\end{array}$ & wzxC-wcaJ & $\begin{array}{l}\text { Troncation of wzxC and } \\
\text { wcaJ genes }\end{array}$ & $\begin{array}{c}\text { wcaJ: Colanic acid biosynthsis } \\
\text { UDP-glucose lipid carrier } \\
\text { transferase } \\
\text { wzxC: Colanic acid exporter }\end{array}$ \\
\hline & 3811225 & $C$ to $A$ & $\begin{array}{l}\text { intergenic } \\
\text { of } \\
\text { mutM- } \\
\text { rpmG }\end{array}$ & n.a & \\
\hline & 3969241 & $G$ to $T$ & $w z z E$ & Nonsense G71Stop & $\begin{array}{l}\text { Enterobacterial Common } \\
\text { Antigen polysaccharide chain } \\
\text { length modulation protein }\end{array}$ \\
\hline & 4022740 & $C$ to $A$ & tatC & Missense S2Y & $\begin{array}{c}\text { TAT translocation system } \\
\text { subunit }\end{array}$ \\
\hline \multicolumn{6}{|c|}{$\begin{array}{l}{ }^{\mathrm{a}} \text { Coordinate is based on NCBI RefSeq NC_000913.3 E. coli MG1655 Genome; }{ }^{\mathrm{b}} \text { Gene function is based on EcoCyc } \\
\text { Database; Green color represents genes involved in extracellular polysaccharides synthesis }\end{array}$} \\
\hline \multicolumn{6}{|c|}{276} \\
\hline 77 & & & & & \\
\hline
\end{tabular}


279 Supplementary Table 3: Bacterial strains and plasmids used in this study

\begin{tabular}{|c|c|c|}
\hline TB28 & MG1655 $\triangle$ laclZYA & 5 \\
\hline RM349 & TB28 $\Delta f t s Z:: k a n$ pOU82-Amp-ftsZ & 6 \\
\hline RM361 & TB28 $\Delta f t s Z:: k a n$ sup1 & This study \\
\hline RM362 & TB28 $\Delta f t s Z:: k a n$ sup5 & This study \\
\hline RM363 & TB28 $\Delta$ ftsZ::kan sup7 & This study \\
\hline RM380 & TB28 $\Delta / p o B:: k a n$ & 7 \\
\hline RM381 & TB28 $\Delta l p p:: k a n$ & 7 \\
\hline RM382 & TB28 $\Delta m r c B:: k a n$ & 7 \\
\hline RM383 & TB28 $\Delta m r c A:: k a n$ & 7 \\
\hline RM384 & TB28 $\Delta / p o A:: k a n$ & 7 \\
\hline RM411 & TB28 $\Delta f t s Z \Delta l p o B:: k a n$ pOU82-Amp-ftsZ & This study \\
\hline RM413 & TB28 $\Delta f t s Z \Delta l p p:: k a n$ pOU82-Amp-ftsZ & This study \\
\hline RM419 & TB28 $\Delta f t s Z \Delta l p p \Delta / p o B:: k a n$ pOU82-Amp-ftsZ & This study \\
\hline RM445 & TB28 $\Delta f t s Z \Delta l p p \Delta l p o B:: k a n$ sup* & This study \\
\hline RM446 & TB28 $\Delta f t s Z:: k a n$ sup5 pOU82-Amp-ftsZ & This study \\
\hline RM447 & TB28 $\Delta f t s Z \Delta l p p \Delta l p o B:: k a n$ sup* ${ }^{*}$ OU82-Amp-ftsZ & This study \\
\hline RM448 & TB28 $\Delta f t s Z \Delta l p p \Delta m r c B:: k a n$ pOU82-Amp-ftsZ & This study \\
\hline RM449 & TB28 $\Delta f t s Z \Delta l p p \Delta m r c A:: k a n$ pOU82-Amp-ftsZ & This study \\
\hline RM450 & TB28 $\Delta$ ftsZ $\Delta l p p \Delta / p o A:: k a n$ pOU82-Amp-ftsZ & This study \\
\hline RM451 & TB28 $\Delta f t s Z \Delta m r c B:: k a n$ pOU82-Amp-ftsZ & This study \\
\hline RM452 & TB28 $\Delta f t s Z \Delta m r c A:: k a n$ pOU82-Amp-ftsZ & This study \\
\hline RM453 & TB28 $\Delta f t s Z \Delta l p o A:: k a n$ pOU82-Amp-ftsZ & This study \\
\hline Plasmid & Relevant Genotype & Reference/Origin \\
\hline $\begin{array}{l}\text { pOU82-Amp- } \\
\text { ftsZ }\end{array}$ & R1-replicon, Amp lacZYA ftsZ & 6 \\
\hline pOU82-Cm-ftsZ & R1-replicon, Cm lacZYA ftsZ & This study \\
\hline pBAD33 & pACYC184, Cm araC Para & Lab Collection \\
\hline pBAD33-IpoB & pACYC184, $C m$ araC $P_{\text {ara- }}-1 p o B$ & 8 \\
\hline pBAD33-Ipp & pACYC184, Cm araC $P_{\text {ara- }}-1 p p$ & This study \\
\hline pBAD33-wcaJ & pACYC184, Cm araC Para-wcaJ & This study \\
\hline pBAD33- $m r c B$ & pACYC184, Cm araC Para-mrcB & This study \\
\hline pBAD24-Ipp & pBR322, Amp araC Para-Ipp & This study \\
\hline pBS58 & pGB2, Sp ftsQAZ & 9 \\
\hline pKG339 & pSC101, $\mathrm{P}_{\text {lac }}:: \operatorname{cop} A \operatorname{Tet}^{\mathrm{R}}$ & 10 \\
\hline pKD46-Sp & $\mathrm{Sp}^{\mathrm{R}}, \lambda \mathrm{Red}$ recombinase expression & 6 \\
\hline
\end{tabular}

kan, kanamycin; cat, chloramphenicol; tet,tetracyclin; Amp, b-lactamase; Sp,spectinomycin lacZ, b-galactosidase; $P_{\text {ara }}$, promoter arabinose; $P_{\text {lac }}$, promoter lactose 


\section{Supplementary Videos}

284 Supplementary video 1: Time-lapse series showing $\Delta f t s Z s u p 5$ cells growing on NA. Phase 285 contrast images were acquired automatically every minute for about $87 \mathrm{~min}$. Scale bar is 3 $286 \mu \mathrm{m}$.

288 Supplementary video 2: Time-lapse series showing $\triangle$ ftsZsup1 cell growing on NA 20mM $289 \mathrm{Mg}^{2+}$, from which the panels in Figure $2 \mathrm{~b}$ were obtained. Phase contrast images were 290 acquired automatically every minute for about $279 \mathrm{~min}$. Scale bar is $3 \mu \mathrm{m}$.

291

292 Supplementary video 3: Time-lapse series showing $\Delta$ ftsZsup7 cell growing on NA 20mM $293 \mathrm{Mg}^{2+}$. Phase contrast images were acquired automatically every minute for about $109 \mathrm{~min}$. 294 Scale bar is $3 \mu \mathrm{m}$.

295

296 Supplementary video 4: Time-lapse series showing $\Delta f t s Z s u p 7$ cell dividing on NA 20mM $297 \mathrm{Mg}^{2+}$, from which the panels in Figure $2 \mathrm{~b}$ were obtained. Phase contrast images were 298 acquired automatically every minute for about $69 \mathrm{~min}$. Scale bar is $3 \mu \mathrm{m}$.

300 Supplementary video 5: Time-lapse series showing $\triangle$ ftsZsup cell dividing on NA $+20 \mathrm{mM}$ $301 \mathrm{Mg}^{2+}$, from which the panels in Figure 2c were obtained. Phase contrast images were 302 acquired automatically every minute for about $90 \mathrm{~min}$. Scale bar is $3 \mu \mathrm{m}$.

Supplementary video 6: Time-lapse series showing RM445 ( $\left.\Delta \mathrm{fts} Z / \Delta / p p / \Delta / p o B_{\text {sup }}\right)$ cell, 305 bearing the plasmid pBAD33-IpoB cell growing on $\mathrm{NA}+20 \mathrm{mM} \mathrm{Mg}^{2+}$ with glucose (Ipp 306 expression repressed). Phase contrast images were acquired automatically every minute for 307 about $209 \mathrm{~min}$. Scale bar is $3 \mu \mathrm{m}$.

309 Supplementary video 7: Time-lapse series showing RM445 ( $\left.\Delta \mathrm{ftsZ} / \Delta / p p / \Delta / p o B_{\text {sup }}\right)$, bearing 310 the plasmid pBAD33-IpoB cell growing on $\mathrm{NA}+20 \mathrm{mM} \mathrm{Mg}^{2+}$ with $I p \circ B$ expression induced 311 (arabinose), from which the panels in Figure 3d were obtained. Phase contrast images were 312 acquired automatically every minute for about $209 \mathrm{~min}$. Scale bar is $3 \mu \mathrm{m}$.

313 


\section{Supplementary References}

316

3171 Sledjeski, D. D. \& Gottesman, S. Osmotic shock induction of capsule synthesis in 318 Escherichia coli K-12. J Bacteriol 178, 1204-1206, (1996).

3192 Glover, W. A., Yang, Y. \& Zhang, Y. Insights into the molecular basis of L-form 320 formation and survival in Escherichia coli. PloS One 4, e7316, (2009).

3213 Bendezu, F. O. \& de Boer, P. A. Conditional lethality, division defects, membrane 322 involution, and endocytosis in mre and $m r d$ shape mutants of Escherichia coli. $J$ 323 Bacteriol 190, 1792-1811, (2008).

3244 Donachie, W. D. The cell cycle of Escherichia coli. Annu Rev Microbiol 47, 199-230, $325 \quad$ (1993).

3265 Bernhardt, T. G. \& de Boer, P. A. The Escherichia coli amidase AmiC is a periplasmic 327 septal ring component exported via the twin-arginine transport pathway. Mol Microbiol $328 \quad$ 48, 1171-1182, (2003).

3296 Mercier, R., Kawai, Y. \& Errington, J. General principles for the formation and 330 proliferation of a wall-free (L-form) state in bacteria. Elife 3, (2014).

3317 Baba, T. et al. Construction of Escherichia coli K-12 in-frame, single-gene knockout 332 mutants: the Keio collection. Molecular Systems Biology 2, 2006 0008, (2006).

3338 Typas, A. et al. Regulation of peptidoglycan synthesis by outer-membrane proteins.

$334 \quad$ Cell 143, 1097-1109, (2010).

$3359 \mathrm{Bi}, \mathrm{E}$. \& Lutkenhaus, J. FtsZ regulates frequency of cell division in Escherichia coli. J $336 \quad$ Bacteriol 172, 2765-2768, (1990).

33710 Jensen, R. B., Grohmann, E., Schwab, H., Diaz-Orejas, R. \& Gerdes, K. Comparison 338 of $c c d$ of $\mathrm{F}$, parDE of RP4, and parD of R1 using a novel conditional replication 339 control system of plasmid R1. Mol Microbiol 17, 211-220, (1995). 